\title{
Stable Palladium Oxide Clusters Encapsulated in Silicalite-1 for Complete Methane Oxidation
}

\author{
Teng Li," Arik Beck," Frank Krumeich, Luca Artiglia, Manoj K. Ghosalya, Maneka Roger, Davide Ferri,
} Oliver Kröcher, Vitaly Sushkevich, Olga V. Safonova, and Jeroen A. van Bokhoven*

Cite This: ACS Catal. 2021, 11, 7371-7382

Read Online

ACCESS | L Wlll Metrics \& More | 国 Article Recommendations | st Supporting Information

ABSTRACT: Zeolite-supported metal catalysts are widely employed in a number of chemical processes, and the stability of the catalytically active species is one of the most critical factors determining the reaction performance. A good example is the $\mathrm{Pd} /$ zeolite catalyst, which provides high activity for methane oxidation but deactivates rapidly under the reaction conditions due to palladium nanoparticle sintering. Although coating the metals with thin shells of porous materials is a promising strategy to address the sintering of metals, it is still challenging to fix small metal particles completely inside zeolite crystals. Here, using an amine-

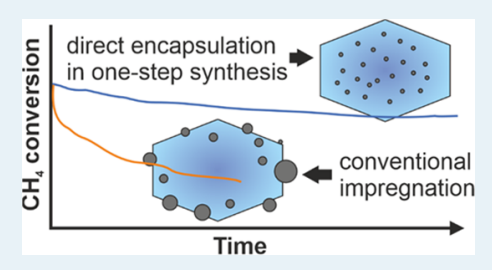
based ligand to stabilize palladium during the zeolite synthesis, we realize the exclusive encapsulation of highly dispersed palladium oxide clusters $(1.8-2.8 \mathrm{~nm})$ in the microporous channels and voids of the nanosized silicalite- 1 crystals. The synthesis conditions of the zeolite-supported catalyst influence the encapsulation degree and the size distribution of metal particles. Thanks to the encapsulation effect of small palladium oxide clusters, together with the inherent properties of silicalite-1 such as low acidity, high hydrophobicity, and high hydrothermal stability, the optimized Pd@silicalite-1 catalyst outperforms the traditional Pd-based catalysts prepared by wetness impregnation, exhibiting both high activity and better stability in the lean methane oxidation reaction. KEYWORDS: palladium oxide, metal encapsulation, zeolite, silicalite-1, methane oxidation, metal sintering, catalyst deactivation

\section{INTRODUCTION}

Sintering of metals under harsh reaction conditions can be inhibited by the zeolite-wall protection as well as other oxides. $^{1-9}$ Therefore, the encapsulation of metal clusters or particles into zeolites attracts a lot of attention. However, the sole presence of well-defined micropores imposes difficulties to catalyst fabrication, and the traditional impregnation and ionexchange methods generally result in nonuniform and large particles on the exterior surface. ${ }^{10-13}$ Introducing larger secondary pores like mesopores $(2-50 \mathrm{~nm})$ or macropores $(>50 \mathrm{~nm})$ to the microporous zeolite demonstrates to be effective to accommodate metal particles. ${ }^{14-17}$ The resulting catalysts not only show high thermal stability in reactions but also facilitate the diffusion of reactants and products. However, the large mesoporous/macroporous voids generally have less restrictions on the metal particle growth and various growth rates of individual particles could lead to a broad size distribution. 2,18,19 Moreover, the exclusive encapsulation of highly dispersed and ultrasmall metals is still difficult to realize, especially in mesoporous zeolites that possess mesoporous voids open to the surface.

Ideally, encapsulating metal species in small and uniform channels and voids within microporous zeolites yields ultrasmall metal particles with high dispersion. Synchronizing the encapsulation of metal species with the crystallization of zeolites has shown success. ${ }^{20-22}$ Different ligands such as ammonia, ethylenediamine, and mercaptosilane are added to the synthesis mixture. Through the ligand-stabilized protocol, encapsulated small metal clusters/particles within different types of aluminosilicate zeolites, such as SOD, GIS, BEA, FAU, and LTA, have been synthesized. Recently, using ethylenediamine as the stabilizing ligand, a series of metal clusters, or even single metal atoms, have been introduced to MFI, FAU, and MWW zeolites. ${ }^{23-31}$ The increased exposure of active sites as well as the high thermal stability of the catalyst makes such metal-encapsulated zeolites promising materials in the propane dehydrogenation, ${ }^{25,30,31}$ decomposition of formic acid, $^{23,24} n$-hexane isomerization, ${ }^{26}$ and ammonia borane hydrolysis. $^{27}$

In comparison to these catalytic reactions, catalytic methane oxidation has rather harsh reaction conditions, namely, high temperatures. Catalytic methane oxidation is important for the utilization of lean-burn natural gas engines since the emission of unburnt methane in the exhaust gas leads to a severe greenhouse effect. ${ }^{32,33}$ Compared to the conventional catalytic materials like $\mathrm{Pd} / \mathrm{Al}_{2} \mathrm{O}_{3}$ and $\mathrm{Pd} / \mathrm{SiO}_{2}$, zeolite-supported palladium catalysts show higher activity for methane combustion at low temperatures $\left(<500{ }^{\circ} \mathrm{C}\right)$ but still suffer from deactivation. ${ }^{34-37}$ On the one hand, the typical reaction

Received: November 9, 2020

Revised: February 19, 2021

Published: June 7, 2021 
temperature for catalytic methane oxidation results in the sintering of palladium particles on the exterior surface and reducing the number of exposed active sites. On the other hand, the presence of water under the practical reaction conditions causes several problems, such as blocking the active palladium site, facilitating the migration of palladium species, and destroying the framework of low-silica zeolites. ${ }^{38-41}$ It is also found that the increased acidity of the zeolite enhances the mobility of palladium over the support. ${ }^{17,36}$ Therefore, searching for a catalyst with low or no palladium mobility and high thermal stability under the reaction conditions is of great importance.

In this work, we report a highly active PdO-encapsulatedsilicalite- 1 catalyst that is resistant to sintering under methane oxidation conditions. Silicalite-1 having MFI topology is selected as the support due to its low acidity, high hydrophobicity, and high hydrothermal stability, which could reduce the mobility of palladium and prevent zeolite degradation. Using ethylenediamine as a stabilizing ligand during synthesis, we studied the effects of different synthesis parameters on palladium encapsulation and found that the optimized Pd@silicalite-1 catalyst showed superior catalytic performance in the complete methane oxidation reaction. Also, the one-pot synthesis procedure is a facile way to prepare stable PdO-encapsulated-zeolite catalysts for methane oxidation since it avoids a series of delicate and time-consuming postsynthesis treatments as reported previously. ${ }^{17,42}$

\section{EXPERIMENTAL SECTION}

2.1. Catalyst Preparation. 2.1.1. Synthesis of Silicalite-1. The nanosized silicalite- 1 was synthesized according to our previous report. ${ }^{43}$ Typically, $8.78 \mathrm{~g}$ of tetrapropylammonium hydroxide (TPAOH) solution (25 wt \% in water) was added to a Teflon reactor containing $8.32 \mathrm{~g}$ of tetraethyl orthosilicate (TEOS) and $20.04 \mathrm{~g}$ of water. The mixture was then gradually heated to $35{ }^{\circ} \mathrm{C}$ and stirred for $6 \mathrm{~h}$ at $500 \mathrm{rpm}$. The resulting zeolite precursor gel has a composition of $1 \mathrm{SiO}_{2} / 0.27$ $\mathrm{TPAOH} / 46 \mathrm{H}_{2} \mathrm{O}$. After homogenization, the obtained precursor was transferred to a $50 \mathrm{~mL}$ stainless steel autoclave equipped with a Teflon liner and heated to $170{ }^{\circ} \mathrm{C}$ for 3 days under static conditions. The as-synthesized solid sample was separated by centrifugation at $15000 \mathrm{rpm}$ for $15 \mathrm{~min}$, washed three times with deionized water, and dried overnight at 100 ${ }^{\circ} \mathrm{C}$. The obtained sample was referred to as "silicalite1 (before)". Calcined silicalite-1 was obtained by calcination in air at $550{ }^{\circ} \mathrm{C}$ for $10 \mathrm{~h}$ with a heating ramp of $5{ }^{\circ} \mathrm{C} \mathrm{min}{ }^{-1}$.

2.1.2. Synthesis of Pd@Silicalite-1. The synthesis of Pd@ silicalite- 1 was similar to that of the silicalite- 1 case except for adding a certain amount of $\left[\mathrm{Pd}\left(\mathrm{NH}_{2} \mathrm{CH}_{2} \mathrm{CH}_{2} \mathrm{NH}_{2}\right)_{2}\right] \mathrm{Cl}_{2}$ solution to the zeolite precursor. The [ $\mathrm{Pd}$ $\left.\left(\mathrm{NH}_{2} \mathrm{CH}_{2} \mathrm{CH}_{2} \mathrm{NH}_{2}\right)_{2}\right] \mathrm{Cl}_{2}$ solution was prepared by dissolving $0.032 \mathrm{~g}$ of $\mathrm{PdCl}_{2}$ in $0.3 \mathrm{~mL}$ of ethylenediamine and $3 \mathrm{~g}$ of water, and then, the solution was added dropwise to the zeolite synthesis mixture. ${ }^{23}$ The resulting zeolite precursor gel has a composition of $1 \mathrm{SiO}_{2} / 0.27 \mathrm{TPAOH} / 46 \mathrm{H}_{2} \mathrm{O} / 0.0045$ [Pd$\left.\left(\mathrm{NH}_{2} \mathrm{CH}_{2} \mathrm{CH}_{2} \mathrm{NH}_{2}\right)_{2}\right] \mathrm{Cl}_{2}$. After stirring for $1 \mathrm{~h}$, the zeolite precursor solution was transferred to a $50 \mathrm{~mL}$ stainless steel autoclave equipped with a Teflon liner and heated to $170{ }^{\circ} \mathrm{C}$ for 3 days under static conditions. The solid sample was treated using the same procedure as described above. The samples before and after calcination were designated as "Pd@ silicalite-1(before)” and “Pd@silicalite-1”, respectively.
2.1.3. Synthesis of Pd/Silicalite-1(IWI). "Pd/silicalite-1(IWI)" was prepared by an incipient wetness impregnation method. Calcined silicalite-1 ( $1.0 \mathrm{~g})$ was mixed with a solution containing $0.02 \mathrm{~g}$ of $\mathrm{PdCl}_{2}, 0.2 \mathrm{~mL}$ of ethylenediamine, and 0.8 $\mathrm{g}$ of water. The mixture was vigorously stirred until the liquid evaporated. Then, the solid was dried overnight at $100{ }^{\circ} \mathrm{C}$ and calcined in air at $550{ }^{\circ} \mathrm{C}$ for $10 \mathrm{~h}$.

2.1.4. Synthesis of Pd@Silicalite-1 $(x=0.0022 P d)$ and Pd@ Silicalite-1 $(x=0.009 P d)$. The synthesis of "Pd@silicalite-1 $(x=$ $0.0022 \mathrm{Pd})$ " and "Pd@silicalite-1 $(x=0.009 \mathrm{Pd})$ " was similar to that of Pd@silicalite-1 except for adding different amounts of $\left[\mathrm{Pd}\left(\mathrm{NH}_{2} \mathrm{CH}_{2} \mathrm{CH}_{2} \mathrm{NH}_{2}\right)_{2}\right] \mathrm{Cl}_{2}$ solution to the zeolite synthesis mixture. For Pd@silicalite-1 $(x=0.0022 \mathrm{Pd})$, the [Pd$\left.\left(\mathrm{NH}_{2} \mathrm{CH}_{2} \mathrm{CH}_{2} \mathrm{NH}_{2}\right)_{2}\right] \mathrm{Cl}_{2}$ solution was prepared by dissolving $0.016 \mathrm{~g}$ of $\mathrm{PdCl}_{2}$ in $0.15 \mathrm{~mL}$ of ethylenediamine and $1.5 \mathrm{~g}$ of water, and then, the solution was added dropwise to the zeolite synthesis mixture. The resulting zeolite precursor gel has a composition of $1 \mathrm{SiO}_{2} / 0.27 \mathrm{TPAOH} / 46 \mathrm{H}_{2} \mathrm{O} / 0.0022[\mathrm{Pd}-$ $\left.\left(\mathrm{NH}_{2} \mathrm{CH}_{2} \mathrm{CH}_{2} \mathrm{NH}_{2}\right)_{2}\right] \mathrm{Cl}_{2}$. For Pd@silicalite-1 $(x=0.009 \mathrm{Pd})$, the $\left[\mathrm{Pd}\left(\mathrm{NH}_{2} \mathrm{CH}_{2} \mathrm{CH}_{2} \mathrm{NH}_{2}\right)_{2}\right] \mathrm{Cl}_{2}$ solution was prepared by dissolving $0.064 \mathrm{~g}$ of $\mathrm{PdCl}_{2}$ in $0.6 \mathrm{~mL}$ of ethylenediamine and 6 $\mathrm{g}$ of water, and then, the solution was added dropwise to the zeolite synthesis mixture. The resulting zeolite precursor gel has a composition of $1 \mathrm{SiO}_{2} / 0.27 \mathrm{TPAOH} / 46 \quad \mathrm{H}_{2} \mathrm{O} /$ $0.009\left[\mathrm{Pd}\left(\mathrm{NH}_{2} \mathrm{CH}_{2} \mathrm{CH}_{2} \mathrm{NH}_{2}\right)_{2}\right] \mathrm{Cl}_{2}$.

2.1.5. Synthesis of Pd@Silicalite-1 $(y=0.45 T P A O H)$ and Pd@Silicalite-1 $(y=0.6 T P A O H)$. The synthesis of "Pd@ silicalite-1 $(y=0.45 \mathrm{TPAOH})$ " and "Pd@silicalite-1 $(y=$ $0.6 \mathrm{TPAOH})$ " was similar to that of Pd@silicalite-1 except for adding different amounts of tetrapropylammonium hydroxide (TPAOH) solution to the zeolite precursor. For Pd@silicalite-1 $(y=0.45 \mathrm{TPAOH}), 14.63 \mathrm{~g}$ of TPAOH solution (25 wt \% in water) was added to a Teflon reactor containing $8.32 \mathrm{~g}$ of TEOS and $15.65 \mathrm{~g}$ of water. The resulting zeolite precursor gel has a composition of $1 \mathrm{SiO}_{2} / 0.45 \mathrm{TPAOH} / 46$ $\mathrm{H}_{2} \mathrm{O} / 0.0045\left[\mathrm{Pd}\left(\mathrm{NH}_{2} \mathrm{CH}_{2} \mathrm{CH}_{2} \mathrm{NH}_{2}\right)_{2}\right] \mathrm{Cl}_{2}$. For Pd@silicalite$1(y=0.6 \mathrm{TPAOH}), 19.51 \mathrm{~g}$ of TPAOH solution $(25 \mathrm{wt} \%$ in water) was added to the Teflon reactor containing $8.32 \mathrm{~g}$ of TEOS and $12 \mathrm{~g}$ of water. The resulting zeolite precursor gel has a composition of $1 \mathrm{SiO}_{2} / 0.6 \mathrm{TPAOH} / 46 \mathrm{H}_{2} \mathrm{O} / 0.0045$ $\left[\mathrm{Pd}\left(\mathrm{NH}_{2} \mathrm{CH}_{2} \mathrm{CH}_{2} \mathrm{NH}_{2}\right)_{2}\right] \mathrm{Cl}_{2}$.

2.1.6. Synthesis of Pd@ZSM-5 and Pd@ZSM-5 ( $x=$ $0.0022 P d)$. The synthesis of "Pd@ZSM-5" was similar to the preparation of Pd@silicalite-1 except for adding a certain amount of $0.153 \mathrm{~g}$ of aluminum nitrate nonahydrate. The resulting zeolite precursor gel has a composition of $1 \mathrm{SiO}_{2} /$ $0.005 \quad \mathrm{Al}_{2} \mathrm{O}_{3} / 0.27 \quad \mathrm{TPAOH} / 46 \quad \mathrm{H}_{2} \mathrm{O} / 0.0045 \quad[\mathrm{Pd}-$ $\left.\left(\mathrm{NH}_{2} \mathrm{CH}_{2} \mathrm{CH}_{2} \mathrm{NH}_{2}\right)_{2}\right] \mathrm{Cl}_{2}$. The synthesis of "Pd@ZSM-5 $(x=$ $0.0022 \mathrm{Pd}$ )" was similar to that of Pd@ZSM-5 except using a reduced amount of $\mathrm{Pd}$ precursor solution. The resulting gel has a composition of $1 \mathrm{SiO}_{2} / 0.005 \mathrm{Al}_{2} \mathrm{O}_{3} / 0.27 \mathrm{TPAOH} / 46 \mathrm{H}_{2} \mathrm{O} /$ $0.0022\left[\mathrm{Pd}\left(\mathrm{NH}_{2} \mathrm{CH}_{2} \mathrm{CH}_{2} \mathrm{NH}_{2}\right)_{2}\right] \mathrm{Cl}_{2}$. The base leaching of Pd@ZSM-5 was carried out based on our previous procedure with $0.1 \mathrm{M} \mathrm{NaOH}$ solution. ${ }^{44}$

2.1.7. Synthesis of Pd@Silicalite-1@ZSM-5. The synthesis of “Pd@silicalite-1@ZSM-5" was carried out by two consecutive crystallization steps. The first step was to synthesize Pd@silicalite-1(before) as seed crystals. In the second step, $10 \mathrm{~g}$ of commercial TPAOH solution was added to a Teflon reactor containing $10.4 \mathrm{~g}$ of TEOS and $19.5 \mathrm{~g}$ of deionized water. Seed crystals $(1 \mathrm{~g})$, obtained from the first crystallization step, were added to the mixture. The mixture was heated to $30{ }^{\circ} \mathrm{C}$, stirred for $24 \mathrm{~h}$ at $500 \mathrm{rpm}$, and heated to 
$80{ }^{\circ} \mathrm{C}$ to remove the ethanol produced. After cooling to ambient temperature, a solution of sodium hydroxide $(0.4 \mathrm{~g})$, aluminum nitrate nonahydrate $(0.284 \mathrm{~g})$, and deionized water $(6.7 \mathrm{~g})$ was added dropwise while stirring vigorously. The mixture was transferred to a $50 \mathrm{~mL}$ stainless steel autoclave equipped with a Teflon liner and heated to $170{ }^{\circ} \mathrm{C}$ for 2 days under static conditions. The solid product was recovered as described above and calcined in air at $550{ }^{\circ} \mathrm{C}$ for $10 \mathrm{~h}$.

2.1.8. Synthesis of Pd@Silicalite-1(450air), Pd@Silicalite1(650air),Pd@Silicalite-1 $\left(450 \mathrm{H}_{2}\right), P d @ S i l i c a l i t e-1\left(550 \mathrm{H}_{2}\right)$, Pd@Silicalite-1 $\left(65 \mathrm{OH}_{2}\right)$, and Pd@Silicalite-1(650 $\mathrm{H}_{2}-650$ air). The synthesis of this series of samples was similar to that of Pd@silicalite-1 except using different atmospheres and temperatures to remove the template. The heating rates in all cases were $5{ }^{\circ} \mathrm{C} \mathrm{min}^{-1}$. Pd@silicalite-1(450air) was obtained by calcining Pd@silicalite-1(before) in air at 450 ${ }^{\circ} \mathrm{C}$ for 10 h 20 min, and Pd@silicalite-1(650air) was obtained by calcining Pd@silicalite-1 (before) in air at $650{ }^{\circ} \mathrm{C}$ for $9 \mathrm{~h} 40$ min.Pd@silicalite-1 $\left(450 \mathrm{H}_{2}\right)$, Pd@silicalite-1 $\left(550 \mathrm{H}_{2}\right)$, and Pd@silicalite-1 $\left(650 \mathrm{H}_{2}\right)$ were obtained by treating Pd@ silicalite-1(before) in a flow of $5 \% \mathrm{H}_{2}$ balanced with $\mathrm{N}_{2}$ at $450{ }^{\circ} \mathrm{C}$ for $10 \mathrm{~h} 20 \mathrm{~min}$, at $550{ }^{\circ} \mathrm{C}$ for $10 \mathrm{~h}$, and at $650{ }^{\circ} \mathrm{C}$ for 9 h $40 \mathrm{~min}$, respectively. Pd@silicalite- $1\left(650 \mathrm{H}_{2}-650\right.$ air $)$ was obtained by calcining Pd@silicalite- $1\left(650 \mathrm{H}_{2}\right)$ in air at $650{ }^{\circ} \mathrm{C}$ for $9 \mathrm{~h} 40 \mathrm{~min}$.

2.1.9. Synthesis of Pd@Silicalite-1(Na),Pd@Silicalite-1(K), and Pd@Silicalite-1(Cs). The synthesis of "Pd@silicalite1(Na)”, “Pd@silicalite-1(K)”, and “Pd@silicalite-1(Cs)” was similar to that of Pd@silicalite-1 except for adding a certain amount of sodium hydroxide $(0.032 \mathrm{~g})$, potassium hydroxide $(0.045 \mathrm{~g})$, and cesium hydroxide $(0.12 \mathrm{~g})$, respectively. The resulting zeolite precursor gel has a composition of $1 \mathrm{SiO}_{2} /$ $0.27 \mathrm{TPAOH} / 46 \mathrm{H}_{2} \mathrm{O} / 0.0045\left[\mathrm{Pd}\left(\mathrm{NH}_{2} \mathrm{CH}_{2} \mathrm{CH}_{2} \mathrm{NH}_{2}\right)_{2}\right] \mathrm{Cl}_{2} /$ $0.02 \mathrm{MOH}(\mathrm{M}=\mathrm{Na}, \mathrm{K}, \mathrm{Cs})$. The solid product was recovered as described above and calcined in air at $550{ }^{\circ} \mathrm{C}$ for $10 \mathrm{~h}$.

2.1.10. Synthesis of $P d / A I_{2} \mathrm{O}_{3} . \mathrm{Pd} / \mathrm{Al}_{2} \mathrm{O}_{3}$ was synthesized by wet impregnation. Alumina powder (SASOL Puralox UF 5/ 230) was stirred for $6 \mathrm{~h}$ at $80{ }^{\circ} \mathrm{C}$ with a palladium nitrate solution (Alfa Aesar) corresponding to $1 \mathrm{wt} \%$ loading of palladium. After drying at $120{ }^{\circ} \mathrm{C}$ for $6 \mathrm{~h}$, the catalyst was calcined in air at $500{ }^{\circ} \mathrm{C}$ for $2 \mathrm{~h}$.

2.2. Catalyst Characterization. Powder X-ray diffraction patterns were collected using a PANalytical X'Pert PRO MPD diffractometer equipped with a $\mathrm{Cu} \mathrm{K} \alpha$ source at ambient conditions. Nitrogen physisorption isotherms were measured with a Micromeritics Tristar instrument at $77 \mathrm{~K}$. Zeolite samples were degassed at $200{ }^{\circ} \mathrm{C}$ under vacuum for $4 \mathrm{~h}$ prior to physisorption measurements. The surface area was derived using the Brunauer-Emmett-Teller (BET) model. The external surface area and micropore volume were derived from constructed the $t$-plots. The total pore volume was determined from a single point measured at $p / p_{0}=0.96$. The metal loading and $\mathrm{Si} / \mathrm{Al}$ ratio were determined by inductively coupled plasma (ICP) analyses carried out using a Horiba Ultra 2 instrument equipped with a photomultiplier tube detector. Thermal gravimetric analysis was performed with a thermogravimetric analyzer TGA/SDTA851e from MettlerToledo. The sample was heated to $750{ }^{\circ} \mathrm{C}$ in air at $20{ }^{\circ} \mathrm{C}$ $\mathrm{min}^{-1}$ heating rate. For the (scanning) transmission electron microscopy ((S)TEM) investigation, the material was dispersed in ethanol and a few drops of the suspension were deposited onto a perforated carbon foil supported on a copper grid. TEM images were obtained with a Tecnai F30 microscope (Thermo Fisher Scientific) operated at an acceleration potential of $300 \mathrm{kV}$. STEM investigations were performed on an aberration-corrected HD-2700CS microscope (Hitachi) operated at $200 \mathrm{kV}$ (cold field emitter). Images were recorded with a high-angle annular dark-field (HAADF) detector. A secondary electron (SE) detector allows one to study the sample morphology. X-ray photoelectron spectroscopy (XPS) and sample depth profiling were performed by varying the excitation X-ray energy at the In Situ Spectroscopy beamline of the Swiss Light Source (SLS), Paul Scherrer Institute, Switzerland. The spectra were recorded under highvacuum conditions at $25^{\circ} \mathrm{C}$. Pd binding energies were referred to as the Si $2 p$ peak for sample charging. The inelastic mean free path (IMFP, $\lambda$ ) values were estimated using QUASES software and $\mathrm{SiO}_{2}$ as the reference material. ${ }^{45}$ The following equation has been used to calculate the attenuation length $(\mathrm{AL}): \mathrm{AL}$ (or information depth) $=3 \lambda \cdot \cos \theta$. Here, $\theta$ corresponds to the angle between the analyzer cone and the sample surface normal. The AL can be defined as the thickness of the sample, from where $95 \%$ of detected signal originates. ${ }^{46}$ $\mathrm{X}$-ray absorption spectroscopy data were acquired in transmission mode at the Pd K-edge $(24.35 \mathrm{keV})$ at the SuperXAS beamline of the Swiss Light Source (SLS), Paul Scherrer Institute, Switzerland. The beam was collimated by a platinumcoated mirror at $2.5 \mathrm{mrad}$ and focused by a platinum-coated toroidal mirror at a spot of $500 \times 200 \mu \mathrm{m}^{2}$. We used a channelcut $\mathrm{Si}(111)$ quickXAS monochromator and quick $15 \mathrm{~mm}$ long ionization chambers filled with argon-nitrogen mixtures. ${ }^{49}$ Fourier transformation of extended X-ray absorption fine structure (EXAFS) functions and data reduction were performed using the Demeter software package. ${ }^{48}$ Fourier transform infrared spectra in the transmission mode were collected using an iS50 machine equipped with a DTGS detector (Thermo Scientific). The samples were pressed to self-supporting wafers ( $\varnothing 16 \mathrm{~mm}, 20 \mathrm{mg}$ ), placed in the custom-made IR cell, and annealed at $450{ }^{\circ} \mathrm{C}$ for $4 \mathrm{~h}$ in dynamic vacuum. After cooling to ambient temperature, the spectra were collected by averaging 128 scans with $4 \mathrm{~cm}^{-1}$ resolution. $\mathrm{CO}$ chemisorption was measured using a Micromeritics AutoChem II 2920 device. Prior to adsorption, $\sim 100$ $\mathrm{mg}$ of the sample was treated in situ at $300{ }^{\circ} \mathrm{C}$ for $30 \mathrm{~min}$ in $10 \% \mathrm{H}_{2} / \mathrm{Ar}$ and cooled down on $\mathrm{He}$ to $40{ }^{\circ} \mathrm{C}$. Pulse chemisorption was carried out under a flow of $\mathrm{He}(30 \mathrm{~mL}$ $\mathrm{min}^{-1}$ ), with pulses of $200 \mu \mathrm{L}$ of $10 \% \mathrm{CO} / \mathrm{He}$ until saturation was reached.

2.3. Evaluation of Catalytic Activity. The activity of the powder catalysts toward methane oxidation was evaluated in two different setups (A and B) consisting of a quartz-glass plug flow reactor (I.D. $4 \mathrm{~mm}$ [A] and $6 \mathrm{~mm}$ [B]), gas flowmeters, heating control, and an outlet gas analysis system (Hiden Analytical QGA [A] and InProcess Instruments GAM 400 [B] mass spectrometer). Fragments with $m / z$ ratios of $2\left(\mathrm{H}_{2}\right), 12$ (C), $15\left(\mathrm{CH}_{4}\right), 16\left(\mathrm{O}_{2}\right), 18\left(\mathrm{H}_{2} \mathrm{O}\right), 28\left(\mathrm{~N}_{2} / \mathrm{CO}\right), 30(\mathrm{NO})$, $32\left(\mathrm{O}_{2}\right)$, and $44\left(\mathrm{CO}_{2}\right)$ were followed. The exothermic effect of the reaction was minimized by diluting the catalyst $(10 \mathrm{mg}$ [A] and $50 \mathrm{mg}[\mathrm{B}], 150-200 \mu \mathrm{m}$ sieve fraction) with cordierite $(200 \mathrm{mg}[\mathrm{A}]$ and $150 \mathrm{mg}[\mathrm{B}], 100-150 \mu \mathrm{m})$.

The long-time stability test under dry conditions of the catalysts was carried out with experimental setup A: Prior to collection of the catalytic data, the catalyst was pretreated in the flow $\left(100 \mathrm{~mL} \mathrm{~min}^{-1}\right)$ of $1 \mathrm{vol} \% \mathrm{CH}_{4}, 4 \mathrm{vol} \% \mathrm{O}_{2}$, and $95 \%$ $\mathrm{N}_{2}$ at $550{ }^{\circ} \mathrm{C}$ for $30 \mathrm{~min}\left(10^{\circ} \mathrm{C} \mathrm{min}{ }^{-1}\right)$ and then cooled to 50 ${ }^{\circ} \mathrm{C}$. Then, the initial activity was measured in a light-off 
Scheme 1. Schematic Illustration of the Preparation of Pd@Silicalite-1 by the One-Pot Synthesis Procedure

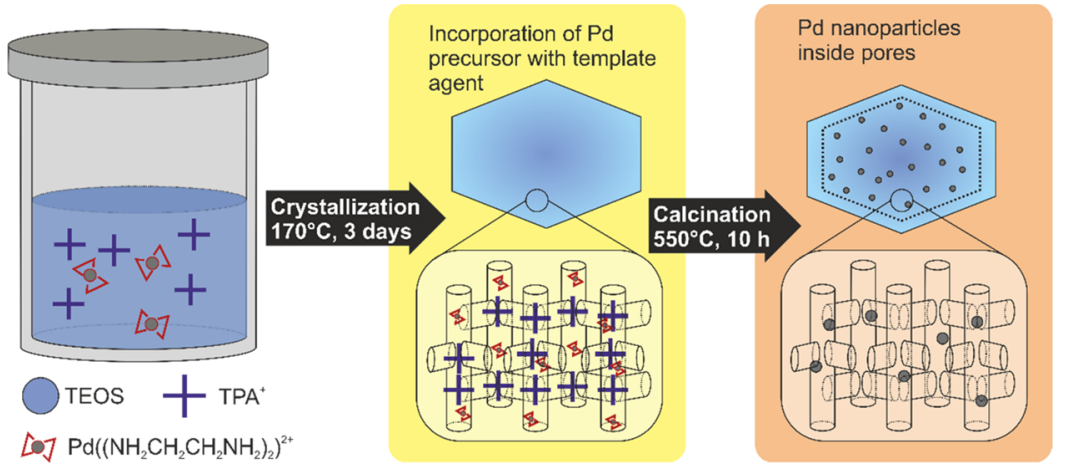

experiment of heating the catalyst to $500{ }^{\circ} \mathrm{C}\left(2.5^{\circ} \mathrm{C} \mathrm{min}^{-1}\right)$ at a gas hourly space velocity (GHSV) of $200000 \mathrm{~h}^{-1}$. After the light-off, the reactor was then cooled to $400{ }^{\circ} \mathrm{C}$ to evaluate the catalytic stability of the catalyst at around $60 \%$ conversion and was kept at this temperature to evaluate its catalytic stability.

To compare with our previous work, ${ }^{33}$ in another catalytic test, we introduced 5 vol \% steam to the methane mixture to evaluate the silicalite-1-supported $\mathrm{Pd}$ catalysts in wet conditions. This test was performed with experimental setup B. The exothermic effect of the reaction was minimized by diluting $83 \mathrm{mg}$ of catalyst (Pd loading, $0.6 \mathrm{wt} \%$ ), which corresponds to $50 \mathrm{mg}$ of $\mathrm{Pd} /$ mordenite (Pd loading, $1.0 \mathrm{wt} \%$ ), with cordierite. Prior to collection of the catalytic data, the catalyst was pretreated in a flow of 1 vol $\% \mathrm{CH}_{4}, 4$ vol $\% \mathrm{O}_{2}$, and $95 \% \mathrm{~N}_{2}$ at $550{ }^{\circ} \mathrm{C}$ for $30 \mathrm{~min}\left(10{ }^{\circ} \mathrm{C} \mathrm{m^{-1 }}\right)$ at $550{ }^{\circ} \mathrm{C}$ and then cooled to $200{ }^{\circ} \mathrm{C}$. Then, the initial activity was measured in a light-off experiment of heating the catalyst to $500{ }^{\circ} \mathrm{C}\left(5^{\circ} \mathrm{C} \min ^{-1}\right)$. After the light-off, the reactor was cooled to $410{ }^{\circ} \mathrm{C}$, and 5 vol $\%$ steam was added to the flow to obtain catalytic stability data in a wet feed.

\section{RESULTS AND DISCUSSION}

\subsection{Encapsulation of Palladium Oxide Clusters into}

Silicalite-1. The overall synthesis procedure for the palladium oxide clusters encapsulated into silicalite-1 (denoted Pd@ silicalite-1) is illustrated in Scheme 1. The synthesis details are described in Section 2, and the zeolite precursor gel used in this work has a composition of $1 \mathrm{SiO}_{2} / 0.27 \mathrm{TPAOH} / 46 \mathrm{H}_{2} \mathrm{O} /$ $0.0045\left[\mathrm{Pd}\left(\mathrm{NH}_{2} \mathrm{CH}_{2} \mathrm{CH}_{2} \mathrm{NH}_{2}\right)_{2}\right] \mathrm{Cl}_{2}$, if not stated otherwise. The template molecules $\left(\mathrm{TPA}^{+}\right)$are expected to occupy the intersectional voids, and the ethylenediamine-stabilized palladium might be located in the unoccupied space, such as in the straight and sinusoidal channels as well as in part of the unoccupied intersectional voids. ${ }^{25}$ After hydrothermal treatment at $170{ }^{\circ} \mathrm{C}$ for 3 days followed by calcination in air to remove the template and ligands, small palladium oxide clusters are encapsulated in the silicalite- 1 crystals. The origin for the selective adsorption of the palladium precursors onto the zeolite could have multiple reasons, such as the stability of the palladium precursor in the mother gel, the blockage of palladium by the template $\mathrm{TPA}^{+}$cations, and the electrostatic interaction between $\left[\mathrm{Pd}\left(\mathrm{NH}_{2} \mathrm{CH}_{2} \mathrm{CH}_{2} \mathrm{NH}_{2}\right)_{2}\right]^{2+}$ and negative charge of the zeolite framework, which still need to be studied. The absence of detectable diffraction peaks corresponding to metallic palladium and palladium oxide crystal structures in the $\mathrm{X}$-ray diffraction pattern indicated that large palladium species were not present (Figure S1). Compared to that of silicalite-1, the micropore volume of $\mathrm{Pd} @$ silicalite- 1 decreased from 0.11 to $0.09 \mathrm{~cm}^{3} \mathrm{~g}^{-1}$ (Table S1), possibly due to the encapsulation of palladium species as well as the partial damage of the zeolite framework (vide infra).

Figure 1a-c shows electron microscopy images of the palladium-containing sample before calcination (denoted $\mathrm{Pd} @$ silicalite-1(before)). The Pd@silicalite-1(before) crystals had well-defined hexagonal prism shapes without any discernible palladium species on the exterior surface (Figure S2). A close examination of the crystals indicated the presence of highly dispersed palladium atoms and small palladium clusters randomly distributed in the crystal (Figure S3). Considering the difficulty to pinpoint the subnanometric palladium clusters/atoms from the STEM images, we only counted the sizes of clusters that were no smaller than $1 \mathrm{~nm}$ and found that the average size of palladium clusters before calcination was about $1.3 \mathrm{~nm}$ (Figure S3). After calcination in air at $550{ }^{\circ} \mathrm{C}$ for $10 \mathrm{~h}$, the zeolite crystals still preserved the original morphology. The absence of palladium species on the exterior surface confirmed that palladium species were still encapsulated after calcination (Figures $1 \mathrm{~d}-\mathrm{f}, \mathrm{S} 4$, and S5). The dispersed palladium clusters/atoms with a size less than $1 \mathrm{~nm}$ cannot be observed anymore, and the average size of palladium-containing clusters increased to $2.3 \mathrm{~nm}$ (Figure 2b). This indicated that the calcination step led to the migration and assembly of palladium atoms to clusters within the microporous channels. The formed palladium-containing clusters were preferentially located in the core part of the silicalite- 1 crystal, and a $20 \mathrm{~nm}$ area from the edge was found to possess very few palladium species (Figure S6). In contrast, the $\mathrm{Pd} /$ silicalite-1(IWI) sample with a similar palladium loading $(\sim 0.6 \mathrm{wt} \%)$ but prepared by the traditional wetness impregnation method possessed a broad size distribution, and very large palladium-containing particles were mainly located on the exterior surface of zeolite crystals (Figures $1 \mathrm{~g}$ and S7).

The exclusive encapsulation of palladium was further confirmed by nondestructive depth profile analysis performed using $\mathrm{X}$-ray photoelectron spectroscopy employing a variation in excitation energy of the X-rays from the synchrotron source. ${ }^{49}$ Figure $1 \mathrm{~h}$ shows the Pd $3 \mathrm{~d}$ photoemission spectra of $\mathrm{Pd} @$ silicalite-1, acquired with photoelectron kinetic energies of $290 \mathrm{eV}$ (surface-sensitive conditions) and $860 \mathrm{eV}$ (bulksensitive conditions). The estimated information depths for such kinetic energy values are ca. 3.2 and $6.7 \mathrm{~nm}$, respectively (Table S2). In both photoemission spectra, no signal was observed, indicating that the palladium species were deeply encapsulated into silicalite-1, consistent with the TEM observation where a $20 \mathrm{~nm}$ area from the crystal edge was nearly free from palladium (Figure S6). For comparison, Pd/ 

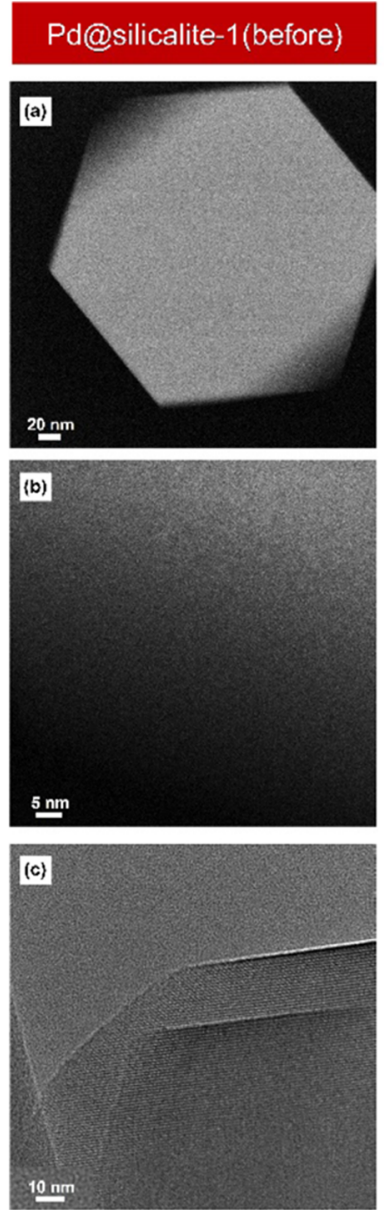
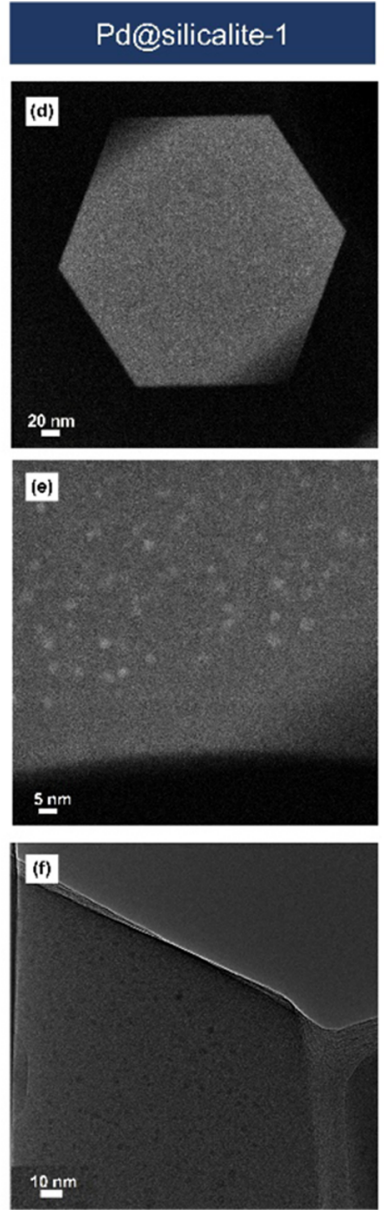

Pd/silicalite-1(IWI)
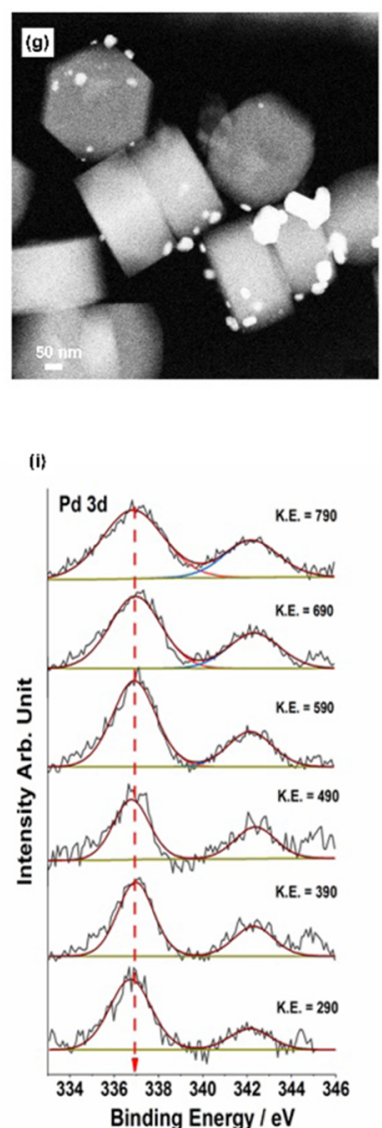

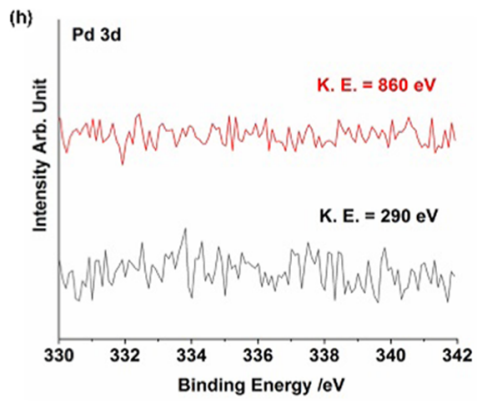

(j)
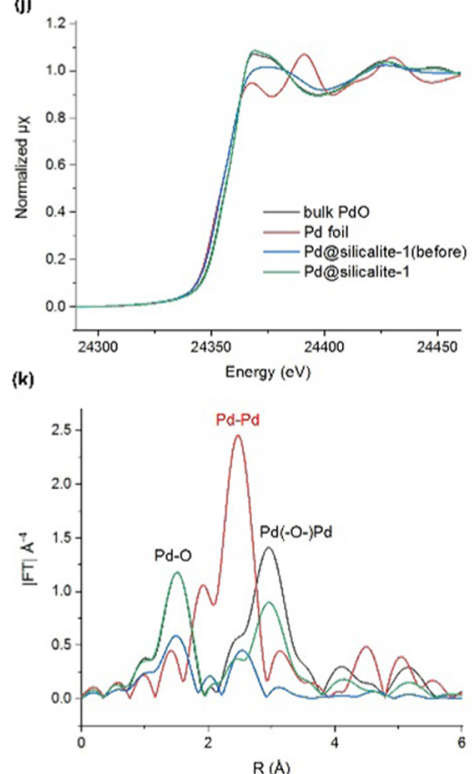

Figure 1. (a, b) HAADF-STEM and (c) TEM images of Pd@silicalite-1(before), (d, e) HAADF-STEM and (f) TEM images of Pd@silicalite-1, (g) HAADF-STEM image of Pd/silicalite-1(IWI), (h) Pd 3d photoemission spectra acquired with 290 and 860 eV photoelectron kinetic energy for Pd@silicalite-1, (i) Pd 3d photoemission spectra acquired between 290 and $760 \mathrm{eV}$ photoelectron kinetic energy for sample Pd/silicalite-1(IWI), (j) X-ray absorption near-edge structure (XANES) spectra, and (k) corresponding Fourier transforms of Pd K-edge extended X-ray absorption fine structure (EXAFS) spectra (nonphase shift corrected) for Pd@silicalite-1(before) and Pd@silicalite-1.

silicalite-1(IWI) was also measured. The Pd $3 \mathrm{~d}_{5 / 2}$ and $\mathrm{Pd} 3 \mathrm{~d}_{3 / 2}$ peaks, centered at ca. 337 and $342.2 \mathrm{eV}$, respectively, can be assigned to PdO (Figure 1i). The line width of the Pd $3 \mathrm{~d}$ peak increased by increasing the photon kinetic energy due to a decrease in resolving power of the beamline monochromator. ${ }^{50}$ Despite that, the $\mathrm{Pd} 3 \mathrm{~d}$ peak intensity did not change significantly in the whole photoelectron kinetic energy range, suggesting that the palladium oxide particles were relatively homogeneously distributed.

To probe the local structure of the palladium species before and after calcination, ex situ Pd K-edge X-ray absorption spectra of Pd@silicalite-1(before) and Pd@silicalite-1 were determined. The X-ray absorption near-edge structure (XANES) spectrum of Pd@silicalite-1 was different from those of the reference samples, while the XANES spectrum of Pd@silicalite-1 was similar to that of the PdO reference sample (Figure 1j), suggesting that the encapsulated palladiumcontaining clusters had an average oxidation state of +2 . The local coordination of palladium was further probed by extended X-ray absorption fine structure (EXAFS) analysis (Figure 1k). In the Fourier transforms (FTs) of the EXAFS spectra, three main peaks (phase shift not corrected) were detected at $\sim 1.6, \sim 2.5$, and $\sim 3.0 \AA$; these peaks were identified as $\mathrm{Pd}-\mathrm{O}$, first shell $\mathrm{Pd}-\mathrm{Pd}$ metallic bonds, and second shell $\mathrm{Pd}-\mathrm{Pd}$ bonds from the $\mathrm{Pd}-\mathrm{O}-\mathrm{Pd}$ structure, respectively. ${ }^{33}$
For Pd@silicalite-1(before), the presence of $\mathrm{Pd}-\mathrm{O}$ bonding and the absence of $\mathrm{Pd}-\mathrm{O}-\mathrm{Pd}$ suggested that part of palladium species were still in the cationic state due to the ligand protection. However, the presence of $\mathrm{Pd}-\mathrm{Pd}$ bonding indicated that a certain fraction of palladium species had been reduced and aggregated, forming small metallic clusters before calcination. For calcined Pd@silicalite-1, the metallic $\mathrm{Pd}-\mathrm{Pd}$ bonding was not observed, and only $\mathrm{Pd}-\mathrm{O}$ and $\mathrm{Pd}-$ $\mathrm{O}-\mathrm{Pd}$ bonding was present (Figure $1 \mathrm{k}$ ). The encapsulated palladium species were oxidized during air calcination to palladium oxide (PdO), which is generally accepted to represent the active phase in the complete methane oxidation reaction. ${ }^{51-53}$

3.2. Influence of Synthesis Parameters on the Palladium Encapsulation. 3.2.1. Removal of Template and Ligand Molecules under Different Conditions. Considering the structural variation and aggregation of palladium species during calcination, studying the influence of postsynthesis conditions for removing the template and ligands from metal encapsulation is necessary. Figures $2 \mathrm{a}-\mathrm{f}$ and $\mathrm{S} 10-\mathrm{S} 15$ show the results of treatments under different atmospheres (air or hydrogen) and operating at different temperatures (450, $\left.550,650{ }^{\circ} \mathrm{C}\right)$. Calcination in air at $450{ }^{\circ} \mathrm{C}$ yielded the palladium oxide clusters with an average size of $2.2 \mathrm{~nm}$ (Figure $2 \mathrm{a}$ ), which was similar to the standard calcination at $550{ }^{\circ} \mathrm{C}$ 


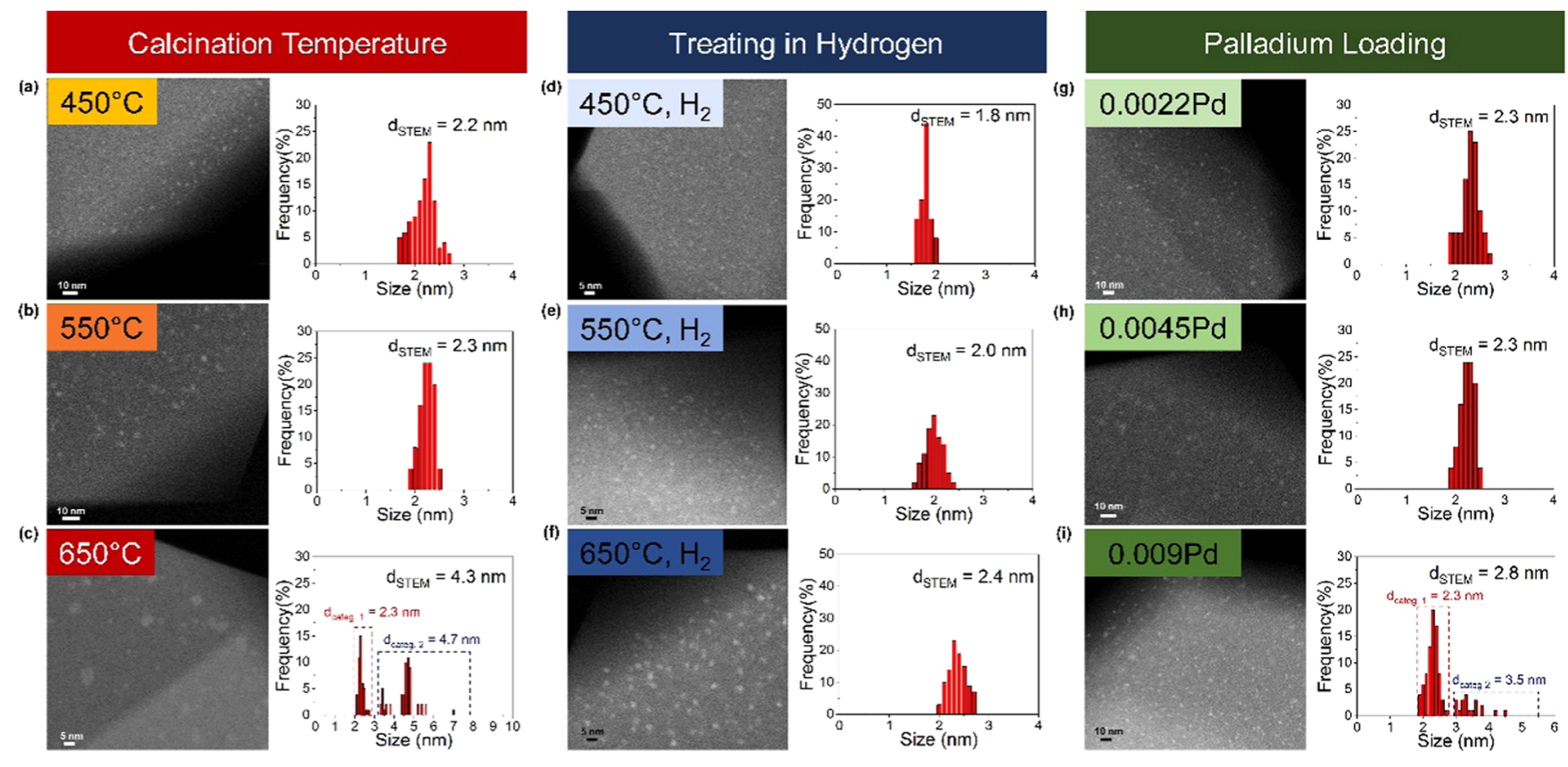

Figure 2. HAADF-STEM images of the palladium-containing samples and the corresponding size distributions of palladium particles. (a-c) Effect of calcination temperature in air: (a) Pd@silicalite-1(450air), (b) Pd@silicalite-1, and (c) Pd@silicalite-1(650air). (d-f) Effect of treating in hydrogen: (d) Pd@silicalite-1 $\left(450 \mathrm{H}_{2}\right),(\mathrm{e}) \mathrm{Pd} @$ silicalite-1 $\left(550 \mathrm{H}_{2}\right)$, and (f) Pd@silicalite-1 $\left(650 \mathrm{H}_{2}\right) .(\mathrm{g}-\mathrm{i})$ Effect of the palladium precursor content in the gel: (g) Pd@silicalite-1 $(x=0.0022 \mathrm{Pd}),(\mathrm{h})$ Pd@silicalite-1, and (i) Pd@silicalite-1 $(x=0.009 \mathrm{Pd})$. Note that images (b) and (h) are from the same sample, i.e., Pd@silicalite-1. The average particle size is calculated according to $d=\sum n_{i} d_{i}^{3} / \sum n_{i} d_{i}^{2} . n_{i}$ stands for the number of particles with size $d_{i}$.

(2.3 $\mathrm{nm}$ in Figure 2b). Calcination at $650{ }^{\circ} \mathrm{C}$ led to more severe aggregation of palladium: a fraction of the palladium species had migrated to the crystal exterior surface and formed particles of sizes larger than $3 \mathrm{~nm}$ (Figures 2c and S11). On the contrary, hydrogen treatment resulted in a less pronounced effect on the palladium aggregation. The temperature increase from 450 to $650{ }^{\circ} \mathrm{C}$ only led to a slight size increase from 1.8 to $2.4 \mathrm{~nm}$ (Figure $2 \mathrm{~d}-\mathrm{f}$ ). The generation of water during air calcination could possibly increase the mobility of palladium and thus favors sintering. ${ }^{38,54,55}$ Although the palladium species were exclusively located within the zeolite crystals, the palladium clusters after hydrogen treatment were in the metallic state. ${ }^{13}$ Follow-up oxidation of the palladium metal in air at $650{ }^{\circ} \mathrm{C}$ led to a slight increase in the average size $(2.7$ $\mathrm{nm}$ ) and nearly all particles were still encapsulated (Figure S15). Therefore, postsynthesis conditions for removing the template and ligands (temperature and atmosphere) do play roles in the aggregation of metal species.

3.2.2. Contents of Palladium Precursor Species and Template Molecules. Increasing the metal loading in the zeolite-support metal catalysts while maintaining well-dispersed metal species improves the catalyst's efficiency per catalyst weight and volume. The influence of the metal precursor content on the metal encapsulation was studied by varying the amounts of $\left[\mathrm{Pd}\left(\mathrm{NH}_{2} \mathrm{CH}_{2} \mathrm{CH}_{2} \mathrm{NH}_{2}\right)_{2}\right] \mathrm{Cl}_{2}$ solution to the zeolite precursor. The resulting zeolite precursor gel had a composition of $1 \quad \mathrm{SiO}_{2} / 0.27 \mathrm{TPAOH} / 46 \quad \mathrm{H}_{2} \mathrm{O} / x[\mathrm{Pd}-$ $\left.\left(\mathrm{NH}_{2} \mathrm{CH}_{2} \mathrm{CH}_{2} \mathrm{NH}_{2}\right)_{2}\right] \mathrm{Cl}_{2}$. The prepared sample with the lowest metal loading (0.35 wt \%) was denoted Pd@silicalite$1(x=0.0022 \mathrm{Pd})$, while that with the highest loading (1.0 wt $\%)$ was denoted Pd@silicalite-1 $(x=0.009 \mathrm{Pd})$. Compared to $\mathrm{Pd} @$ silicalite-1 that has an $x$ value of 0.0045 (Figure 2h), the decreased palladium precursor content for Pd@silicalite-1 $(x=$ $0.0022 \mathrm{Pd}$ ) did not lead to an obvious change in the size distribution of metal oxides, and the average size of clusters was still about $2.3 \mathrm{~nm}$ (Figures $2 \mathrm{~g}$ and S16). However, in Pd@ silicalite-1 $(x=0.009 \mathrm{Pd})$, the particles showed a bimodal distribution (Figures $2 \mathrm{~h}$ and S17). The first category of particles $(<3 \mathrm{~nm})$ that had an average size of $2.3 \mathrm{~nm}$ was still encapsulated, while the second category of particles $(>3 \mathrm{~nm}$ ) had migrated to the exterior surface. This suggests that there should be some competition between individual palladium atoms and clusters in occupying the microporous channels and voids of the zeolite. Apparently, palladium concentration that exceeds a saturation limit leads to the extrusion of surplus palladium species from the zeolite channels and to the formation of large particles on the exterior surface.

Although the template molecules and ligand-stabilized palladium species are expected to occupy different places in the channels, ${ }^{25}$ a competition between palladium and template might exist. To prove that, we increased the content of TPAOH in the synthesis mixture and prepared Pd@silicalite$1(y=0.45 \mathrm{TPAOH})$. The resulting palladium oxide particles also followed a bimodal distribution, and the average size was $3.1 \mathrm{~nm}$ (Figure S18). The absence of large palladium particles before calcination indicated that the variation of $\mathrm{pH}$ in the present case did not cause precipitation. Therefore, the formation of larger particles for this sample occurred during calcination. However, a further increase of TPAOH content $(y$ $=0.6 \mathrm{TPAOH})$ caused precipitation of palladium precursors during zeolite crystallization due to the increased basicity. As a result, only large palladium oxide particles were observed on the exterior surface (Figure S19). These results suggest that increasing the amount of template could not only increase the competition with palladium in occupying the zeolite microporous channels but also possibly cause the precipitation of palladium due to the increased concentration of the base in the synthesis mixture. Overall, both the contents of palladium 

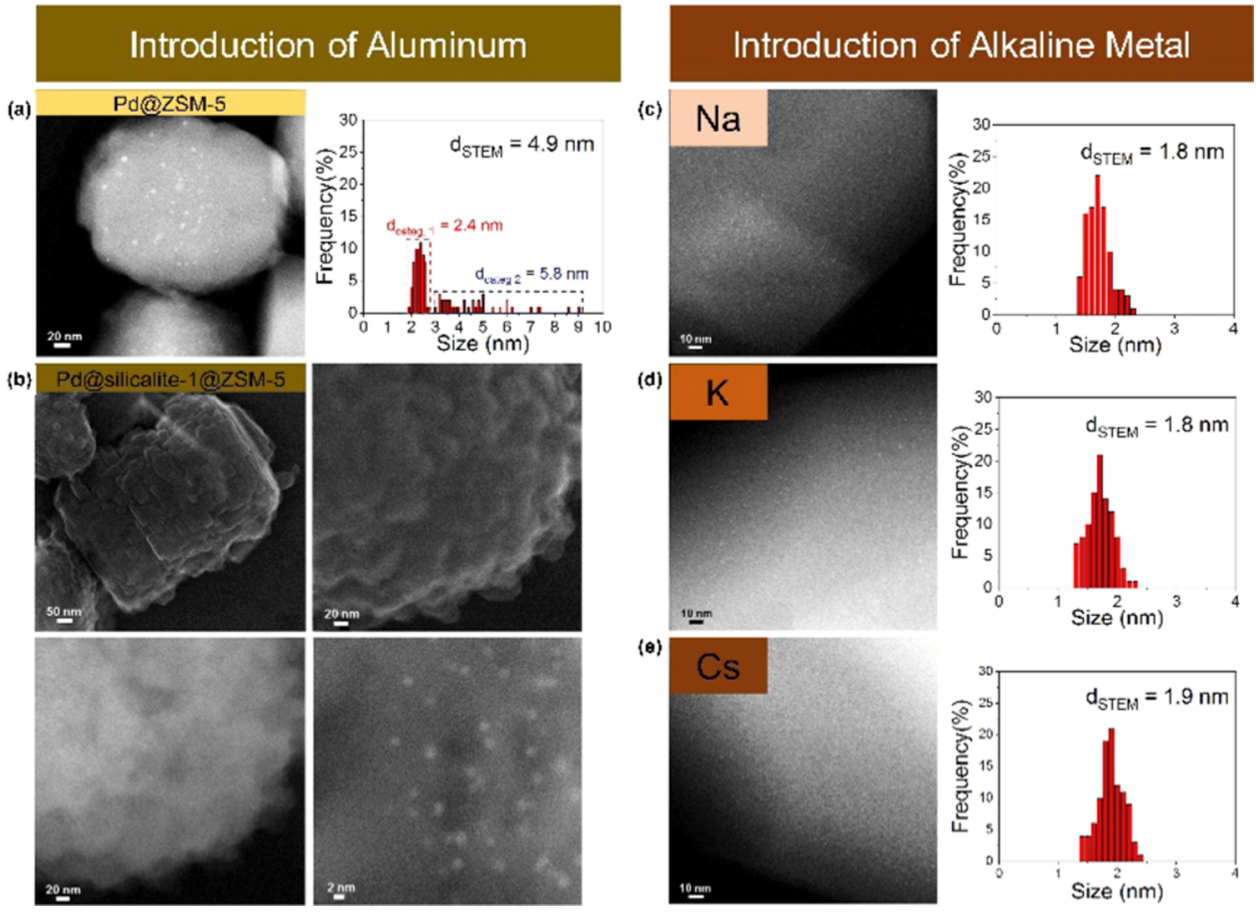

Figure 3. STEM images of the palladium-containing samples and the corresponding size distributions of palladium oxide particles. (a, b) Introduction of aluminum: (a) Pd@ZSM-5 and (b) Pd@silicalite-1@ZSM-5. (c-e) Effect of adding alkaline metals: (c) Pd@silicalite-1(Na), (d) Pd@silicalite-1(K), and (e) Pd@silicalite-1(Cs). In the (b) series of images, the right-down image was deliberately taken from a crystal without a well-covered shell.

precursor species and template molecules need to be adjusted carefully to achieve exclusive metal encapsulation.

3.2.3. Introduction of Aluminum. Bifunctional catalysts having acid sites and metal or metal oxide particles are widely used in many catalysis processes. Considering the importance of preparation of such bifunctional catalysts, the one-step synthesis procedure was also tested for the aluminosilicate ZSM-5 zeolite, with the purpose to introduce acid sites and metal sites simultaneously. The synthesis of Pd@ZSM-5 was similar to the preparation of Pd@silicalite-1 except for adding a certain amount of aluminum nitrate in the mother gel. The obtained catalyst had a rough surface with protrusions, and the $\mathrm{Si} / \mathrm{Al}$ ratio was about 100 . The palladium loading over Pd@ ZSM-5 was only $0.31 \%$, smaller than the $0.6 \%$ palladium loading for Pd@silicalite-1, indicating that part of palladium species in the precursor solution were not eventually included in the catalyst. Besides, the size distribution of metals followed a bimodal distribution, and palladium oxide particles were observed on the exterior surface (Figures 3a and S20). Given that the ZSM-5 crystals synthesized with the $\mathrm{TPA}^{+}$template usually have aluminum-zoning, a base-leaching experiment was conducted over this sample to probe the aluminum distribution. The presence of hollow zeolite crystals after leaching indicated that these ZSM-5 crystals have aluminum zoning, i.e., possessing an aluminum-rich rim and an aluminum-poor core (Figure S21). ${ }^{56}$ Considering the possible self-competition of palladium species in occupying microporous channels, we also prepared a low-metal loading ( $0.2 \mathrm{wt}$ $\%)$ sample, i.e., Pd@ZSM-5 $(x=0.0022 \mathrm{Pd})$. The average metal particle size was reduced over Pd@ZSM-5 $(x=0.0022 \mathrm{Pd})$, but part of palladium species were still found on the exterior surface (Figure S22). The preferential electrostatic interaction between $\mathrm{AlO}_{4}{ }^{-}$tetrahedral and palladium species as well as the uneven aluminum distribution over the ZSM-5 crystals might be the real reasons for the incomplete encapsulation of palladium in ZSM-5 by the one-step synthesis procedure.

To avoid the interaction of aluminum and palladium during zeolite synthesis, separating the introduction of aluminum with that of palladium species to the zeolite might be a good alternative. Based on this assumption, we synthesized a Pd@ silicalite-1@ZSM-5 catalyst with a core-shell structure by two consecutive crystallization steps (Figure S23). Pd@silicalite1 (before) was used as seeds and placed into a zeolite precursor gel containing aluminum precursors. The ZSM-5 zeolite was expected to grow on the exterior surface of seed crystals in the second crystallization process. The resulting crystals (measured $\mathrm{Si} / \mathrm{Al}$ ratio of ca. 52) had an aggregated morphology consisting of many small nanocrystals on the surface (Figure 3b), indicating the successful coverage of a ZSM-5 shell on the silicalite-1 core. However, the ZSM-5 coverage posed difficulty for the identification of palladium oxide clusters in the catalyst, and only from a few zeolite crystals without full coverage of ZSM-5 shell, small palladium oxide clusters could still be clearly observed. The average size of the clusters was similar to that of Pd@silicalite-1, suggesting that the encapsulated palladium species in silicalite-1 did not aggregate during the second crystallization process. The successful preparation of the Pd@silicalite-1@ZSM-5 catalyst also provides a strategy to design a bifunctional catalyst with both acid sites and encapsulated metal or metal oxide clusters.

3.2.4. Inclusion of Alkaline Metals. Considering the frequent utilization of alkaline metals (mainly $\mathrm{Na}, \mathrm{K}$ ) as mineralizing agents in the zeolite synthesis, the influence of different alkaline metals on palladium encapsulation was also investigated. The same molar amounts of sodium hydroxide, potassium hydroxide, and cesium hydroxide were deliberately added to the zeolite synthesis mixture to prepare Pd@silicalite1(Na), Pd@silicalite-1(K), and Pd@silicalite-1(Cs), respec- 
tively. The introduction of alkaline metals did not affect the exclusive encapsulation of palladium in silicalite-1, and all of the catalysts had similar palladium loadings (Table 1).

Table 1. Elemental Analysis Results of the Pd-Containing Samples

\begin{tabular}{lccc}
\multicolumn{1}{c}{ sample name } & $\begin{array}{c}\mathrm{Pd} \\
\text { (wt \%) }\end{array}$ & $\begin{array}{c}\mathrm{Na}(\mathrm{K}, \mathrm{Cs}) \\
\text { (wt \%) }\end{array}$ & $\begin{array}{r}\mathrm{Si} / \\
\mathrm{Al}\end{array}$ \\
Pd@silicalite-1 & 0.60 & & \\
Pd/silicalite-1(IWI) & 0.60 & & \\
Pd@silicalite-1( $x=0.0022 \mathrm{Pd})$ & 0.35 & & \\
Pd@silicalite-1( $x=0.009 \mathrm{Pd})$ & 1.0 & & \\
Pd@silicalite-1( $y=0.45 \mathrm{TPAOH})$ & 0.45 & & \\
Pd@silicalite-1@ZSM-5 & 0.15 & & \\
Pd@silicalite-1(Na) & 0.62 & 0.20 & \\
Pd@silicalite-1(K) & 0.63 & 0.61 & \\
Pd@silicalite-1(Cs) & 0.60 & 1.02 & \\
\hline
\end{tabular}

Interestingly, compared to $\mathrm{Pd@silicalite-1,} \mathrm{the} \mathrm{average}$ palladium oxide cluster size showed a slight decrease for all of the alkaline-metal-containing samples (Figure 3c-e). Wang et al. have proposed that sodium and potassium may reduce some void spaces of the channels and limit the growth of palladium oxide clusters. ${ }^{23}$ This is plausible speculation considering that alkaline metal cations have larger ionic radii than protons. Regarding the $-\mathrm{OH}$ groups, four main bands were observed in the infrared spectra (Figure S27). The peaks at $3745 \mathrm{~cm}^{-1}$ can be ascribed to the external silanols, while those at 3726 and $3700 \mathrm{~cm}^{-1}$ can be ascribed to the internal silanols. ${ }^{57}$ The broad peak at $3500 \mathrm{~cm}^{-1}$ is due to the formation of silanol nests, which are generally associated with the presence of internal defects in silicalite- 1 . The silicalite- 1 sample without palladium possessed abundant internal defects, as reflected by the presence of silanol nests and the high peak intensity at $3726 \mathrm{~cm}^{-1}$. ${ }^{43}$ The introduction of palladium resulted in a further increase of the concentration of defects, as the intensity of the peak at $3500 \mathrm{~cm}^{-1}$ for Pd@silicalite-1 increased significantly. This could be associated with the inclusion of palladium, which somehow destroyed the zeolite framework and thus created more defects. For all alkalinemetal-containing samples, the absence of the broad peak at $3500 \mathrm{~cm}^{-1}$ indicated that the introduction of alkaline metals decreased the concentration of internal silanol nests. Considering that the internal defects are generally more spacious than the intact microporous channels and thus can facilitate molecule migration, we speculate that the reduction of defects caused by alkaline metal inclusion might also contribute to the formation of smaller metal clusters.

3.3. Performance of Pd@Silicalite-1 in Methane Oxidation. The low acidity of zeolite supports is beneficial for the activity of Pd-based catalysts in lean methane oxidation. ${ }^{42}$ In aluminosilicate zeolites, the acidity can be reduced via ion exchange. Complete exchange and preservation of the protons with another cation is difficult to achieve and subsequently catalysts generally show remaining acid sites. ${ }^{33}$ To address this problem, using pure-silica zeolites as the catalyst support is attractive because the absence of cation exchange capacity prevents strong acid site formation. Therefore, the Pd@silicalite-1 catalyst presents a suitable candidate for the complete combustion of methane. To evaluate the general catalytic performance and the efficiency of the PdO nanoparticle incorporation into the zeolite body, the Pd@silicalite-1 and the Pd/silicalite-1(IWI) were tested in lean methane oxidation under dry and wet conditions.

In the light-off and -out comparison (Figure 4a), Pd@ silicalite- 1 and the $\mathrm{Pd} /$ silicalite-1(IWI) show very similar catalytic activity, which is reflected in almost identical temperatures of $50 \%$ methane conversion (T50) (dry, 335 vs $330{ }^{\circ} \mathrm{C}$; wet, 375 vs $370{ }^{\circ} \mathrm{C}$ ). The activation energies (Figure $4 \mathrm{~d}$ and Table 2$)$ for the dry catalyst are in a similar range (87$\left.100 \mathrm{~kJ} \mathrm{~mol}^{-1}\right)$ and are in agreement with literature studies. ${ }^{52,58}$ In wet conditions, the activation energy increases to 125-135 $\mathrm{kJ} \mathrm{mol}^{-1} \cdot 33,59$ In summary, the catalytic behavior of the two catalysts is very similar, even though $\mathrm{PdO}$ is present in two very different particle sizes (Table 2). Given that $\mathrm{Pd}$ is anchored on the same silicalite- 1 , no differences due to the support should arise, so these results can be rationalized in at least two ways. First, CO chemisorption results of $\mathrm{Pd} @$ silicalite-1 (Table 2) showed lower CO adsorption than expected for Pd nanoparticles of $2.3 \mathrm{~nm}$, as determined by STEM. This suggests that a fraction of the Pd particles inside silicalite-1 do not participate in the reaction due to pore blockage. In addition, recently it was found that $\mathrm{PdO}$ nanoparticles larger than $7 \mathrm{~nm}$ have much higher activity for $\mathrm{CH}_{4}$ oxidation. ${ }^{59}$ Consequently, the loss in $\mathrm{Pd}$ dispersion can be compensated with an increase in intrinsic activity. These findings show potential routes for the further improvement of the catalyst, e.g., by the introduction of mesopores into silicalite-1. Nevertheless, the present catalyst's activity with rates of $0.11 \mathrm{~mol}_{\mathrm{CH}_{4}} \mathrm{~mol}_{\mathrm{Pd}}{ }^{-1} \mathrm{~s}^{-1}$ (dry) and $0.025 \mathrm{~mol}_{\mathrm{CH}_{4}}$ $\mathrm{mol}_{\mathrm{Pd}}{ }^{-1} \mathrm{~s}^{-1}$ (wet) at $350{ }^{\circ} \mathrm{C}$ is competitive to the most active reported Pd catalysts. ${ }^{52,59-61}$

Besides the low-temperature activity, catalyst stability is crucial for the application of Pd-based catalysts for complete methane combustion. Nanoparticle sintering is a major contributor to the deactivation of catalysts in methane oxidation. High sintering resistance can be achieved by various strategies. $^{62}$ Most of these strategies involve multistep synthesis protocols or a series of delicate and time-consuming postsynthesis treatments. ${ }^{17,42,63}$ The one-pot synthesis described here yields a Pd@silicalite-1 catalyst with exclusive encapsulation of palladium oxide clusters in the zeolite and the complete elimination of aluminum-related acid sites, which suppresses the migration and aggregation of palladium. Figure $4 \mathrm{~b}$ shows the stability test for both catalysts at $400{ }^{\circ} \mathrm{C}$ (GHSV of $200000 \mathrm{~h}^{-1}$ ). The amount of catalyst was adjusted to yield an initial methane conversion of $\sim 70 \%$. The reaction was conducted for up to $65 \mathrm{~h}$. Pd/silicalite-1(IWI) showed a $~ 50 \%$ conversion decline during the first $17 \mathrm{~h}$ reaction, while the Pd@silicalite-1 catalyst displayed a $\sim 20 \%$ conversion decline during the initial $45 \mathrm{~h}$ reaction. After $45 \mathrm{~h}$, the conversion level stabilized and was maintained for another $20 \mathrm{~h}$. The final catalytic activity at $400{ }^{\circ} \mathrm{C}$ is $0.37 \mathrm{~mol}_{\mathrm{CH}_{4}} \mathrm{~mol}_{\mathrm{Pd}}{ }^{-1} \mathrm{~s}^{-1}$, which is still high.

STEM analysis of the spent catalysts showed the size variation of metal oxide particles (Figure 4e,f). The average size of palladium oxide particles for Pd@silicalite-1 only exhibited a slight increase, from 2.3 to $2.7 \mathrm{~nm}$ (Figure 4e). In contrast, due to the lack of encapsulation, the palladium oxide particles of $\mathrm{Pd} /$ silicalite-1(IWI) showed obvious aggregation after the reaction (Figure $4 \mathrm{f}$ ). The distinct variation of particle sizes during the reaction explains the stability difference of two samples. For the spent Pd@silicalite-1 catalyst, we found that more than $80 \%$ of the particles were still less than $3 \mathrm{~nm}$ and 


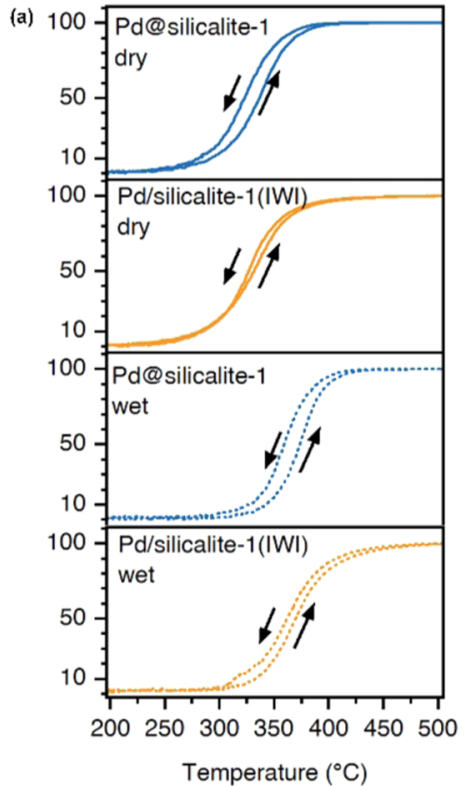

(e)
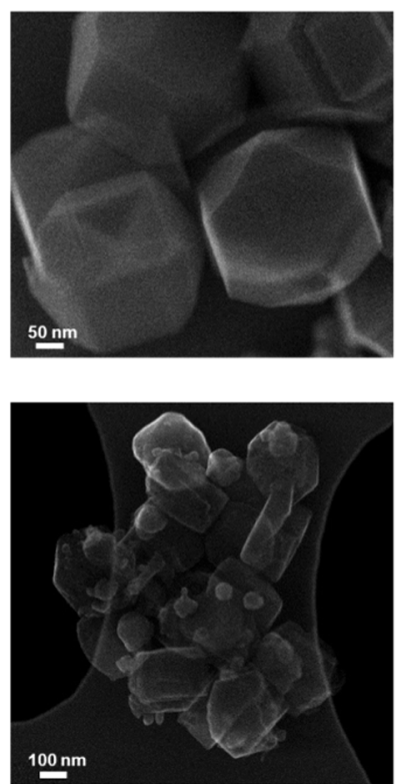
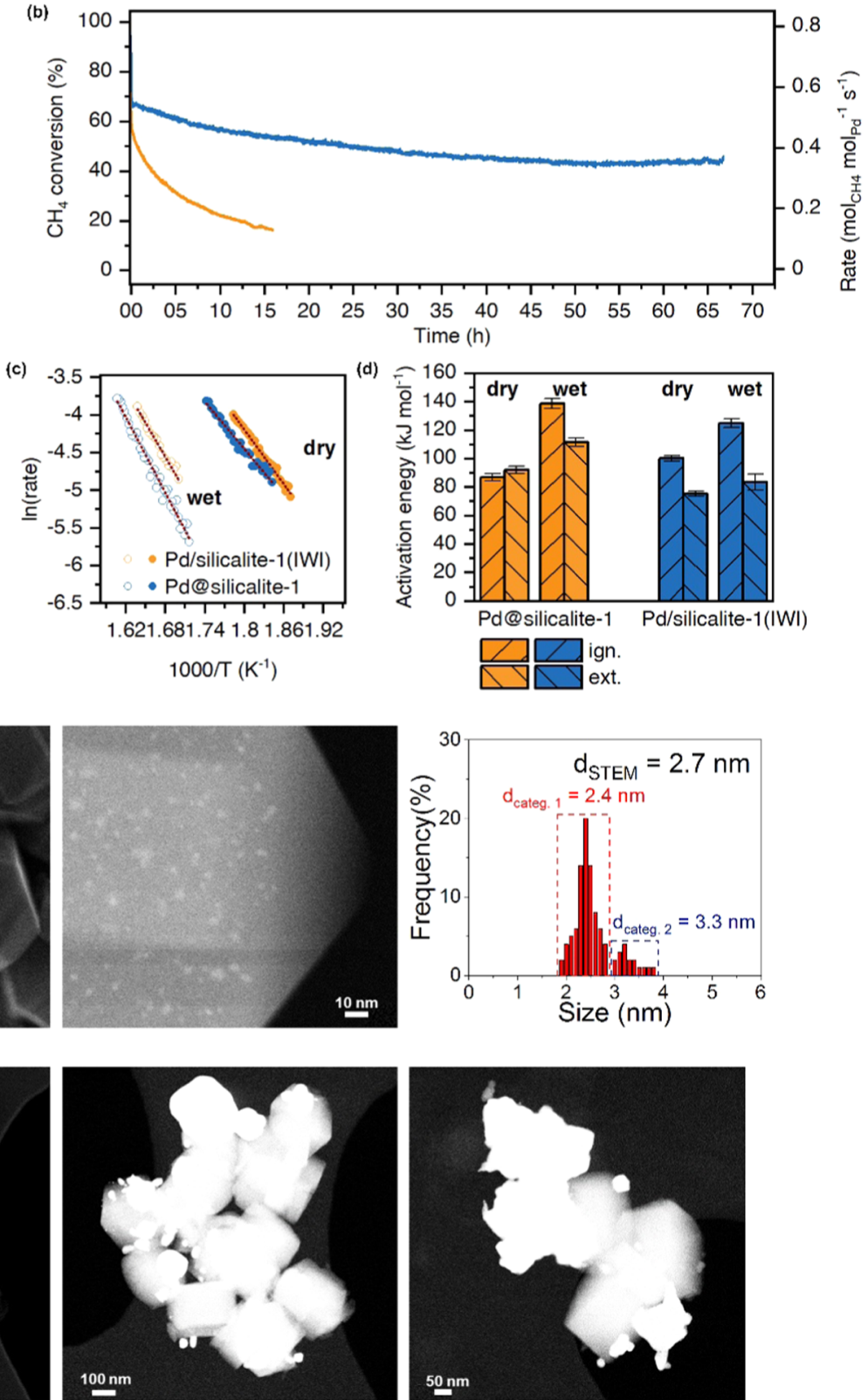

Figure 4. Catalytic activity of Pd@silicalite-1 and Pd/silicalite-1(IWI) in complete methane oxidation: (a) Light-off curves, (b) 65 h stability test at $400{ }^{\circ} \mathrm{C}$, (c) Arrhenius plots of the light-off curves (ignition), and (d) corresponding activation energies. SE- and HAADF-STEM images of (e) spent Pd@silicalite-1 catalyst and the corresponding size distribution of palladium oxide particles and (f) spent Pd/silicalite-1(IWI) catalyst. Conditions: 1 vol $\% \mathrm{CH}_{4}, 4$ vol $\% \mathrm{O}_{2}$, and $95 \% \mathrm{~N}_{2}$, bal. $\mathrm{N}_{2}$; GHSV $=200000 \mathrm{~h}^{-1}$.

Table 2. Catalytic Results for the Pd@Silicalite-1 and Pd/Silicalite-1(IWI) Based on the Ignition Curve of the Light-Off Experiment

\begin{tabular}{|c|c|c|c|c|c|c|c|c|c|}
\hline & dispersion & $\begin{array}{c}\text { particle size } \\
\text { from CO } \\
\text { chemisorption } \\
(\mathrm{nm})\end{array}$ & $\begin{array}{c}\text { average } \\
\text { particle } \\
\text { size from } \\
\text { STEM } \\
(\mathrm{nm})\end{array}$ & $275{ }^{\circ} \mathrm{C}$ (dry) & $\begin{array}{l}\text { rate at } \\
\left(\mathrm{mol}_{\mathrm{CH}_{4}} \mathrm{~mol}_{\mathrm{Pd}}{ }^{-1} \mathrm{~s}^{-1}\right)\end{array}$ & $\begin{array}{c}\text { activation } \\
\text { energy } \\
(\text { dry }) \\
\left(\mathrm{kJ} \mathrm{mol}^{-1}\right)\end{array}$ & $350{ }^{\circ} \mathrm{C}$ (wet) & $\begin{array}{l}\text { rate at } \\
\left(\mathrm{mol}_{\mathrm{CH}_{4}} \mathrm{~mol}_{\mathrm{Pd}}{ }^{-1} \mathrm{~s}^{-1}\right)\end{array}$ & $\begin{array}{c}\text { activation } \\
\text { energy } \\
\text { (wet) } \\
\left(\mathrm{kJ} \mathrm{mol}^{-1}\right)\end{array}$ \\
\hline Pd@silicalite-1 & $14.8 \%$ & 6.3 & 2.3 & & 0.118 & $87 \pm 3$ & & 0.0260 & $138 \pm 4$ \\
\hline $\begin{array}{l}\text { Pd/silicalite- } \\
\text { 1(IWI) }\end{array}$ & $4.6 \%$ & 20.1 & 25.8 & & 0.116 & $100 \pm 2$ & & 0.0376 & $125 \pm 3$ \\
\hline
\end{tabular}

those larger particles $(>3 \mathrm{~nm}$ ) were rarely observed on the exterior surface. A similar stability test in wet conditions is depicted in Figure S28b. Here, an additional comparison was made to an acidic catalyst, i.e., $\mathrm{Pd} / \mathrm{Al}_{2} \mathrm{O}_{3}$. $\mathrm{Pd} / \mathrm{Al}_{2} \mathrm{O}_{3}$ exhibited a rapid deactivation within the first $4 \mathrm{~h}$ on stream, while the catalysts using silicalite- 1 support showed better stability in the presence of water. The methane conversion decline with reaction time was observed over the $\mathrm{Pd} /$ silicalite-1(IWI) catalyst due to the sintering of palladium oxide particles. In comparison, over the Pd@silicalite-1 catalyst, above 95\% 
methane conversion without a discernible conversion decline during the whole reaction test period suggests better stability of this sample.

\section{CONCLUSIONS}

Through the ligand-stabilized protocol, small palladium oxide clusters with an average size of $\sim 2.3 \mathrm{~nm}$ can be exclusively encapsulated in the hydrophobic silicalite- 1 by the one-pot synthesis procedure. The encapsulation and the size distribution of metal particles can be modulated by tuning the synthesis conditions, including the postsynthesis treatment conditions for removing the template and ligands, the contents of palladium precursor and zeolite template molecules, the presence of aluminum, and the inclusion of alkaline metals in the synthesis mixture. The optimized Pd@silicalite-1 catalyst, with small and highly dispersed encapsulated palladium oxide clusters, exhibits high activity and long-time stability in the complete methane oxidation reaction, which may serve as a starting point for designing better catalysts for specific catalytic reaction.

\section{ASSOCIATED CONTENT}

\section{(s) Supporting Information}

The Supporting Information is available free of charge at https://pubs.acs.org/doi/10.1021/acscatal.0c04868.

Further information regarding the characterization of different catalysis, including TEM, STEM, $\mathrm{N}_{2}$ physisorption, XRD, TGA, FT-IR, XPS, and catalytic tests (PDF)

\section{AUTHOR INFORMATION}

\section{Corresponding Author}

Jeroen A. van Bokhoven - Department of Chemistry and Applied Bioscience, Institute for Chemical and Bioengineering, ETH Zurich, 8093 Zurich, Switzerland; Paul Scherrer Insitute, CH-5232 Villigen, Switzerland; 이이.org/00000002-4166-2284; Email: jeroen.vanbokhoven@ chem.ethz.ch

\section{Authors}

Teng Li - Department of Chemistry and Applied Bioscience, Institute for Chemical and Bioengineering, ETH Zurich, 8093 Zurich, Switzerland; (1) orcid.org/0000-0003-4926-1837

Arik Beck - Department of Chemistry and Applied Bioscience, Institute for Chemical and Bioengineering, ETH Zurich, 8093 Zurich, Switzerland

Frank Krumeich - Department of Chemistry and Applied Bioscience, Institute for Chemical and Bioengineering, ETH Zurich, 8093 Zurich, Switzerland; ㅇo이.org/0000-00015625-1536

Luca Artiglia - Paul Scherrer Insitute, CH-5232 Villigen, Switzerland; 이이.orid.org/0000-0003-4683-6447

Manoj K. Ghosalya - Department of Chemistry and Applied Bioscience, Institute for Chemical and Bioengineering, ETH Zurich, 8093 Zurich, Switzerland; Paul Scherrer Insitute, CH-5232 Villigen, Switzerland

Maneka Roger - Paul Scherrer Insitute, CH-5232 Villigen, Switzerland; Ecole polytechnique fédérale de Lausanne (EPFL), Institute of Chemical Sciences and Engineering, $\mathrm{CH}$ 1015 Lausanne, Switzerland

Davide Ferri - Paul Scherrer Insitute, CH-5232 Villigen, Switzerland; 이이.org/0000-0002-9354-5231
Oliver Kröcher - Paul Scherrer Insitute, CH-5232 Villigen, Switzerland; Ecole polytechnique fédérale de Lausanne (EPFL), Institute of Chemical Sciences and Engineering, $\mathrm{CH}$ 1015 Lausanne, Switzerland; (1) orcid.org/0000-00027268-7257

Vitaly Sushkevich - Paul Scherrer Insitute, CH-5232 Villigen,

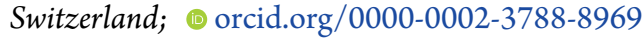

Olga V. Safonova - Paul Scherrer Insitute, CH-5232 Villigen,

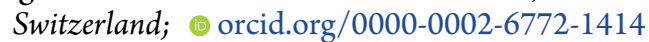

Complete contact information is available at:

https://pubs.acs.org/10.1021/acscatal.0c04868

\section{Author Contributions}

${ }$ T.L. and A.B. contributed equally to this work.

Notes

The authors declare no competing financial interest.

\section{ACKNOWLEDGMENTS}

The authors thank the Scientific Center for Optical and Electron Microscopy (ScopeM) of ETH Zurich for technical support, the In Situ Spectroscopy beamline for assistance in ambient pressure X-ray photoelectron spectroscopy experiments, and the SuperXAS beamline for the assistance in X-ray adsorption spectroscopy at the Swiss Light Source (SLS). Dr. Amy Knorpp is acknowledged for TGA assistance. Dr. Jie Zhu, Dr. Manoj Ravi, and Dr. Zupeng Chen are acknowledged for ICP assistance. T.L. thanks the China Scholarship Council (CSC) for financial support (201506450010). A.B. and J.A.v.B. acknowledge the SNSF project 200021_178943. M.C.R. and D.F. acknowledge the SNSF project 200021_175786.

\section{REFERENCES}

(1) Balkus, K. J.; Gabrielov, A. G. Zeolite Encapsulated Metal Complexes. In Inclusion Chemistry with Zeolites: Nanoscale Materials by Design; Springer, 1995; pp 159-184.

(2) Farrusseng, D.; Tuel, A. Perspectives on zeolite-encapsulated metal nanoparticles and their applications in catalysis. New J. Chem. 2016, 40, 3933-3949.

(3) Zhan, B.-Z.; White, M. A.; Sham, T.-K.; Pincock, J. A.; Doucet, R. J.; Rao, K. R.; Robertson, K. N.; Cameron, T. S. Zeolite-confined nano- $\mathrm{RuO}_{2}: \mathrm{A}$ green, selective, and efficient catalyst for aerobic alcohol oxidation. J. Am. Chem. Soc. 2003, 125, 2195-2199.

(4) Cui, T.; Ke, W.; Zhang, W.; Wang, H.; Li, X.; Chen, J. Encapsulating Palladium Nanoparticles Inside Mesoporous MFI Zeolite Nanocrystals for Shape-Selective Catalysis. Angew. Chem., Int. Ed. 2016, 55, 9178-9182.

(5) Liu, C.; Liu, J.; Yang, S.; Cao, C.; Song, W. Palladium Nanoparticles Encapsulated in a Silicalite-1 Zeolite Shell for SizeSelective Catalysis in Liquid-Phase Solution. ChemCatChem 2016, 8, $1279-1282$.

(6) Zhu, J.; Osuga, R.; Ishikawa, R.; Shibata, N.; Ikuhara, Y.; Kondo, J. N.; Ogura, M.; Yu, J.; Wakihara, T.; Liu, Z.; Okuba, T. Ultrafast Encapsulation of Metal Nanoclusters into MFI Zeolite in the Course of Its Crystallization: Catalytic Application for Propane Dehydrogenation. Angew. Chem., Int. Ed. 2020, 59, 19669-19674.

(7) Liu, J.; Liu, J.; Zhao, Z.; Wei, Y.; Song, W. Fe-Beta@ $\mathrm{CeO}_{2}$ coreshell catalyst with tunable shell thickness for selective catalytic reduction of $\mathrm{NO}_{\mathrm{x}}$ with $\mathrm{NH}_{3}$. AlChE J. 2017, 63, 4430-4441.

(8) Liu, J.; Liu, J.; Zhao, Z.; Tan, J.; Wei, Y.; Song, W. Fe/Beta@ SBA-15 core-shell catalyst: Interface stable effect and propene poisoning resistance for no abatement. AlChE J. 2018, 64, 39673978.

(9) Liu, J.; Zhao, Z.; Xu, C.; Liu, J. Structure, synthesis, and catalytic properties of nanosize cerium-zirconium-based solid solutions in environmental catalysis. Chin. J. Catal. 2019, 40, 1438-1487. 
(10) Wang, N.; Sun, Q.; Yu, J. Ultrasmall Metal Nanoparticles Confined within Crystalline Nanoporous Materials: A Fascinating Class of Nanocatalysts. Adv. Mater. 2019, 31, No. 1803966.

(11) Shamzhy, M.; Opanasenko, M.; Concepción, P.; Martínez, A. New trends in tailoring active sites in zeolite-based catalysts. Chem. Soc. Rev. 2019, 48, 1095-1149.

(12) Wang, C.; Wang, L.; Zhang, J.; Wang, H.; Lewis, J. P.; Xiao, F. Product selectivity controlled by zeolite crystals in biomass hydrogenation over a palladium catalyst. J. Am. Chem. Soc. 2016, 138, $7880-7883$.

(13) Zhang, J.; Wang, L.; Zhang, B.; Zhao, H.; Kolb, U.; Zhu, Y.; Liu, L.; Han, Y.; Wang, G.; Wang, C.; Su, D.; Gates, B. C.; Xiao, F. Sinter-resistant metal nanoparticle catalysts achieved by immobilization within zeolite crystals via seed-directed growth. Nat. Catal. 2018, $1,540-546$

(14) Möller, K.; Bein, T. Mesoporosity-a new dimension for zeolites. Chem. Soc. Rev. 2013, 42, 3689-3707.

(15) Hartmann, M.; Machoke, A. G.; Schwieger, W. Catalytic test reactions for the evaluation of hierarchical zeolites. Chem. Soc. Rev. 2016, 45, 3313-3330.

(16) Gu, J.; Zhang, Z.; Hu, P.; Ding, L.; Xue, N.; Peng, L.; Guo, X.; Lin, M.; Ding, W. Platinum nanoparticles encapsulated in MFI zeolite crystals by a two-step dry gel conversion method as a highly selective hydrogenation catalyst. ACS Catal. 2015, 5, 6893-6901.

(17) Petrov, A. W.; Ferri, D.; Kröcher, O.; van Bokhoven, J. A. Design of stable palladium-based zeolite catalysts for complete methane oxidation by post-synthesis zeolite modification. ACS Catal. 2019, 9, 2303-2312.

(18) Fodor, D.; Ishikawa, T.; Krumeich, F.; van Bokhoven, J. A. Synthesis of Single Crystal Nanoreactor Materials with Multiple Catalytic Functions by Incipient Wetness Impregnation and Ion Exchange. Adv. Mater. 2015, 27, 1919-1923.

(19) Laprune, D.; Tuel, A.; Farrusseng, D.; Meunier, F. Highly dispersed nickel particles encapsulated in multi-hollow silicalite-1 single crystals-Effects of siliceous deposits and phosphorous species on the catalytic performances. Chem CatChem 2017, 9, 2297-2307.

(20) Choi, M.; Wu, Z.; Iglesia, E. Mercaptosilane-assisted synthesis of metal clusters within zeolites and catalytic consequences of encapsulation. J. Am. Chem. Soc. 2010, 132, 9129-9137.

(21) Goel, S.; Wu, Z.; Zones, S. I.; Iglesia, E. Synthesis and catalytic properties of metal clusters encapsulated within small-pore (SOD, GIS, ANA) zeolites. J. Am. Chem. Soc. 2012, 134, 17688-17695.

(22) Goel, S.; Zones, S. I.; Iglesia, E. Encapsulation of metal clusters within MFI via interzeolite transformations and direct hydrothermal syntheses and catalytic consequences of their confinement. J. Am. Chem. Soc. 2014, 136, 15280-15290.

(23) Wang, N.; Sun, Q.; Bai, R.; Li, X.; Guo, G.; Yu, J. In situ confinement of ultrasmall $\mathrm{Pd}$ clusters within nanosized silicalite-1 zeolite for highly efficient catalysis of hydrogen generation. J. Am. Chem. Soc. 2016, 138, 7484-7487.

(24) Sun, Q.; Wang, N.; Bing, Q.; Si, R.; Liu, J.; Bai, R.; Zhang, P.; Jia, M.; Yu, J. Subnanometric hybrid Pd-M $(\mathrm{OH})_{2}, \mathrm{M}=\mathrm{Ni}$, Co, clusters in zeolites as highly efficient nanocatalysts for hydrogen generation. Chem 2017, 3, 477-493.

(25) Liu, L.; Lopez-Haro, M.; Lopes, C. W.; Li, C.; Concepcion, P.; Simonelli, L.; Calvino, J. J.; Corma, A. Regioselective generation and reactivity control of subnanometric platinum clusters in zeolites for high-temperature catalysis. Nat. Mater. 2019, 18, 866-873.

(26) Liu, Y.; Li, Z.; Yu, Q.; Chen, Y.; Chai, Z.; Zhao, G.; Liu, S.; Cheong, W.-C.; Pan, Y.; Zhang, Q.; Gu, L.; Zheng, L.; Wang, Y.; Lu, Y.; Wang, D.; Chen, C.; Peng, Q.; Liu, Y.; Liu, L.; Chen, J.; Li, Y. A General Strategy for Fabricating Isolated Single Metal Atomic Sites Catalysts in Y Zeolite. J. Am. Chem. Soc. 2019, 141, 9305-9311.

(27) Sun, Q.; Wang, N.; Zhang, T.; Bai, R.; Mayoral, A.; Zhang, P.; Zhang, Q.; Terasaki, O.; Yu, J. Zeolite-Encaged Single-Atom Rh Catalysis: Highly-Efficient Hydrogen Generation and Shape-Selective Tandem Hydrogenation of Nitroarenes. Angew. Chem., Int. Ed. 2019, $58,2-9$.
(28) Liu, L.; Lopez-Haro, M.; Meira, D. M.; Concepcion, P.; Calvino, J.; Corma, A. Regioselective Generation of Single-Site Ir Atoms and their Evolution into Stabilized Subnanometric Ir Clusters in MWW Zeolite. Angew. Chem., Int. Ed. 2020, 59, 15695-15702.

(29) Liu, L.; Lopez-Haro, M.; Lopes, C. W.; Rojas-Buzo, S.; Concepcion, P.; Manzorro, R.; Simonelli, L.; Sattler, A.; Serna, P.; Calvino, J.; Corma, A. Structural modulation and direct measurement of subnanometric bimetallic $\mathrm{PtSn}$ clusters confined in zeolites. Nat. Catal. 2020, 3, 628-638.

(30) Wang, Y.; Hu, Z.; Lv, X.; Chen, L.; Yuan, Z. Ultrasmall PtZn bimetallic nanoclusters encapsulated in silicalite-1 zeolite with superior performance for propane dehydrogenation. J. Catal. 2020, $385,61-69$.

(31) Sun, Q.; Wang, N.; Fan, Q.; Zeng, L.; Mayoral, A.; Miao, S.; Yang, R.; Jiang, Z.; Zhou, W.; Zhang, J.; Zhang, T.; Xu, J.; Zhang, P.; Cheng, J.; Yang, D.; Jia, R.; Li, L.; Zhang, Q.; Wang, Y.; Terasaki, O.; $\mathrm{Yu}, \mathrm{J}$. Subnanometer Bimetallic Platinum-Zinc Clusters in Zeolites for Propane Dehydrogenation. Angew. Chem., Int. Ed. 2020, 59, 1945019459.

(32) Cargnello, M.; Jaén, J. D.; Garrido, J. H.; Bakhmutsky, K.; Montini, T.; Gámez, J. C.; Gorte, R.; Fornasiero, P. Exceptional activity for methane combustion over modular $\mathrm{Pd} @ \mathrm{CeO} 2$ subunits on functionalized $\mathrm{Al}_{2} \mathrm{O}_{3}$. Science 2012, 337, 713-717.

(33) Petrov, A. W.; Ferri, D.; Krumeich, F.; Nachtegaal, M.; van Bokhoven, J. A.; Kröcher, O. Stable complete methane oxidation over palladium based zeolite catalysts. Nat. Commun. 2018, 9, No. 2545.

(34) Petrov, A. W.; Ferri, D.; Tarik, M.; Kröcher, O.; van Bokhoven, J. A. Deactivation Aspects of Methane Oxidation Catalysts Based on Palladium and ZSM-5. Top. Catal. 2017, 60, 123-130.

(35) Maeda, H.; Kinoshita, Y.; Reddy, K.; Muto, K.; Komai, S.; Katada, N.; Niwa, M. Activity of palladium loaded on zeolites in the combustion of methane. Appl. Catal., A 1997, 163, 59-69.

(36) Okumura, K.; Matsumoto, S.; Nishiaki, N.; Niwa, M. Support effect of zeolite on the methane combustion activity of palladium. Appl. Catal., B 2003, 40, 151-159.

(37) Okumura, K.; Shinohara, E.; Niwa, M. Pd loaded on high silica beta support active for the total oxidation of diluted methane in the presence of water vapor. Catal. Today 2006, 117, 577-583.

(38) Gholami, R.; Alyani, M.; Smith, K. Deactivation of Pd catalysts by water during low temperature methane oxidation relevant to natural gas vehicle converters. Catalysts 2015, 5, 561-594.

(39) Setiawan, A.; Friggieri, J.; Hosseiniamoli, H.; Kennedy, E. M.; Dlugogorski, B. Z.; Adesina, A. A.; Stockenhuber, M. Towards understanding the improved stability of palladium supported on TS-1 for catalytic combustion. Phys. Chem. Chem. Phys. 2016, 18, 1052810537.

(40) Li, X.; Wang, X.; Roy, K.; van Bokhoven, J. A.; Artiglia, L. Role of Water on the Structure of Palladium for Complete Oxidation of Methane. ACS Catal. 2020, 10, 5783-5792.

(41) Li, Y.; Armor, J. Catalytic combustion of methane over palladium exchanged zeolites. Appl. Catal., B 1994, 3, 275-282.

(42) Losch, P.; Huang, W.; Vozniuk, O.; Goodman, E. D.; Schmidt, W.; Cargnello, M. Modular Pd/zeolite composites demonstrating the key role of support hydrophobic/hydrophilic character in methane catalytic combustion. ACS Catal. 2019, 9, 4742-4753.

(43) Li, T.; Krumeich, F.; Ihli, J.; Ma, Z.; Ishikawa, T.; Pinar, A. B.; van Bokhoven, J. A. Heavy atom labeling enables silanol defect visualization in silicalite-1 crystals. Chem. Commun. 2019, 55, 482485.

(44) Li, T.; Ma, Z.; Krumeich, F.; Knorpp, A. J.; Pinar, A. B.; Van Bokhoven, J. A. Properties Modification of Nanosized Hollow Zeolite Crystals by Desilication. ChemNanoMat 2018, 4, 992-999.

(45) Tanuma, S.; Powell, C. J.; Penn, D. R. Calculations of electorn inelastic mean free paths. II. Data for 27 elements over the 50-2000 eV range. Surf. Interface Anal. 1991, 17, 911-926.

(46) Hofmann, S. Auger-and X-ray Photoelectron Spectroscopy in Materials Science: A User-Oriented Guide; Springer Science \& Business Media: 2012; Vol. 49. 
(47) Müller, O.; Nachtegaal, M.; Just, J.; Luetzenkirchen-Hecht, D.; Frahm, R. Quick-EXAFS setup at the SuperXAS beamline for in situ X-ray absorption spectroscopy with $10 \mathrm{~ms}$ time resolution. J. Synchrotron Radiat. 2016, 23, 260-266.

(48) Ravel, B.; Newville, M. ATHENA, ARTEMIS, HEPHAESTUS: data analysis for X-ray absorption spectroscopy using IFEFFIT. J. Synchrotron Radiat. 2005, 12, 537-541.

(49) Roy, K.; Artiglia, L.; van Bokhoven, J. A. Ambient Pressure Photoelectron Spectroscopy: Opportunities in Catalysis from Solids to Liquids and Introducing Time Resolution. ChemCatChem 2018, 10, 666-682.

(50) Li, T.; Roy, K.; Krumeich, F.; Artiglia, L.; Huthwelker, T.; van Bokhoven, J. A. Variation of Aluminium Distribution in Small-Sized ZSM-5 Crystals during Desilication. Chem. - Eur. J. 2019, 25, 1587915886.

(51) Xu, J.; Ouyang, L.; Mao, W.; Yang, X.; Xu, X.; Su, J.; Zhuang, T.; Li, H.; Han, Y. Operando and kinetic study of low-temperature, lean-burn methane combustion over a $\mathrm{Pd} / \gamma-\mathrm{Al}_{2} \mathrm{O}_{3}$ catalyst. ACS Catal. 2012, 2, 261-269.

(52) Goodman, E. D.; Dai, S.; Yang, A.; Wrasman, C. J.; Gallo, A.; Bare, S. R.; Hoffman, A. S.; Jaramillo, T. F.; Graham, G. W.; Pan, X.; Cargnello, M. Uniform Pt/Pd bimetallic nanocrystals demonstrate platinum effect on palladium methane combustion activity and stability. ACS Catal. 2017, 7, 4372-4380.

(53) Yang, J.; Peng, M.; Ren, G.; Qi, H.; Zhou, X.; Xu, J.; Deng, F.; Chen, Z.; Zhang, J.; Liu, K.; Pan, X.; Liu, W.; Su, Y.; Li, W.; Qiao, B.; Ma, D.; Zhang, T. Hydrothermally stable irreducible oxide-modified $\mathrm{Pd} / \mathrm{MgAl}_{2} \mathrm{O}_{4}$ catalyst for methane combustion. Angew. Chem., Int. Ed. 2020, 59, 18522-18526.

(54) Lamber, R.; Jaeger, N.; Schulz-Ekloff, G. Metal-support interaction in the $\mathrm{Pd} / \mathrm{SiO}_{2}$ system: Influence of the support pretreatment. J. Catal. 1990, 123, 285-297.

(55) Escandón, L. S.; Niño, D.; Díaz, E.; Ordóñez, S.; Díez, F. V. Effect of hydrothermal ageing on the performance of Ce-promoted $\mathrm{PdO} / \mathrm{ZrO}_{2}$ for methane combustion. Catal. Commun. 2008, 9, 22912296.

(56) Li, T.; Krumeich, F.; Chen, M.; Ma, Z.; van Bokhoven, J. A. Defining aluminum-zoning during synthesis of ZSM-5 zeolites. Phys. Chem. Chem. Phys. 2020, 22, 734-739.

(57) Barbera, K.; Bonino, F.; Bordiga, S.; Janssens, T. V.; Beato, P. Structure-deactivation relationship for ZSM-5 catalysts governed by framework defects. J. Catal. 2011, 280, 196-205.

(58) Willis, J. J.; Gallo, A.; Sokaras, D.; Aljama, H.; Nowak, S. H.; Goodman, E. D.; Wu, L.; Tassone, C. J.; Jaramillo, T. F.; AbildPedersen, F.; Cargnello, M. Systematic structure-property relationship studies in palladium-catalyzed methane complete combustion. ACS Catal. 2017, 7, 7810-7821.

(59) Murata, K.; Ohyama, J.; Yamamoto, Y.; Arai, S.; Satsuma, A. Methane Combustion over $\mathrm{Pd} / \mathrm{Al}_{2} \mathrm{O}_{3}$ Catalysts in the Presence of Water: Effects of Pd Particle Size and Alumina Crystalline Phase. ACS Catal. 2020, 10, 8149-8156.

(60) Willis, J. J.; Goodman, E. D.; Wu, L.; Riscoe, A. R.; Martins, P.; Tassone, C. J.; Cargnello, M. Systematic identification of promoters for methane oxidation catalysts using size-and composition-controlled Pd-based bimetallic nanocrystals. J. Am. Chem. Soc. 2017, 139, 11989-11997.

(61) Murata, K.; Kosuge, D.; Ohyama, J.; Mahara, Y.; Yamamoto, Y.; Arai, S.; Satsuma, A. Exploiting Metal-Support Interactions to Tune the Redox Properties of Supported Pd Catalysts for Methane Combustion. ACS Catal. 2020, 10, 1381-1387.

(62) Goodman, E. D.; Schwalbe, J. A.; Cargnello, M. Mechanistic understanding and the rational design of sinter-resistant heterogeneous catalysts. ACS Catal. 2017, 7, 7156-7173.

(63) O’Neill, B. J.; Jackson, D. H.; Lee, J.; Canlas, C.; Stair, P. C.; Marshall, C. L.; Elam, J. W.; Kuech, T. F.; Dumesic, J. A.; Huber, G. W. Catalyst design with atomic layer deposition. ACS Catal. 2015, 5, $1804-1825$. 